\title{
Judeus de Castela em Portugal no final da Idade Media: onomástica e fontes documentais*
}

\author{
María José Ferro Tavares** \\ Universidade Aberta (r.)
}

Judíos de Castilla en Portugal, de fines del siglo XiV a comienzos del siglo XVi: ONOMÁSTICA Y FUENTES DOCUMENTALES.- Mediante el recurso a documentación en buena medida inédita de la cancillería real y procesos inquisitoriales, la autora realiza una lectura diacrónica de la presencia y establecimiento de judíos de origen hispánico en Portugal desde la instauración de la Casa de Avís y hasta después del bautismo forzado de 1497. En esta segunda parte se exponen ejemplos de la movilidad de los judíos llegados al reino como consecuencia de la inestabilidad social y las políticas regias.

Palabras Clave: historia de los judíos; Portugal; onomástica; movilidad; cambio social y cultural.

Castilian Jews in Portugal at the End of the $14^{\mathrm{TH}}$ Until the Beginning of the $16^{\mathrm{Th}}$ Century: Onomastics and Documentary Sources.- Using mainly unpublished sources of the royal chancery and Inquisition proceedings the author provides profiles of individuals and their families among a Jewish minority of Spanish origin in Portugal from the restoration of the Avis dynasty (1383) to the expulsions and forced baptism of the Jews. In this second part, it is exemplified the mobility of the Jewish immigrants as a consequence of the social and political instability.

KeYwords: History of the Jews; Portugal; Onomastics; Mobility; Social and Cultural Change.

\footnotetext{
* Continuación de Sefarad 74 (2014), 89-144.

***mariajosetavares@gmail.com
} 
2. OfícIOS, COMÉRCIO E CRIMES ECONÓMICOS OU OUTROS, NA ORIGEM DAS MigRaÇões dos Judeus CASTElhanos PaRa PoRtugal (E PORTUGUeSES PARA CASTEla)

A fixação dos judeus no reino ou a sua saída era alvo de permissão régia. Caso um judeu desejasse mudar-se para outro reino deveria obter permissão do soberano, caso contrário seria penalizado nos bens que aqui deixasse. Foi o que aconteceu com Judas Simão que residiu em Lisboa e partiu para Alburquerque (Badajoz). Os seus bens foram doados a José Alhaquim, servidor de $\mathrm{D}$. Afonso $\mathrm{V}^{206}$.

A guerra no norte de África e a expansão ultramarina obrigava os reis de Portugal a estarem atentos ao desenvolvimento da arte da guerra e à produção de armas de fogo em que alguns judeus castelhanos se tinham especializado. Este facto fazia com que estes artífices se sentissem também atraídos por Portugal. Fora o caso de Samuel Verdugo, castelhano, residente em Elvas. Era ferreiro e fazia armas de guerra que guardava num armazém. D. Afonso V outorgava-lhe uma carta de privilégio que o isentava do pagamento dos pedidos lançados pelo rei e pela comuna. Estávamos em $1459^{207}$. Anos mais tarde, Samuel Verdugo, perfeitamente integrado nesta comunidade judaica, representava-a no acordo feito com o concelho de modo a que a comuna mantivesse as suas portas abertas até ao sino de correr sem ser penalizada pelo alcaide, porquanto os cristãos iam à judiaria adquirir bens de que necessitavam até muito $\operatorname{tarde}^{208}$. Talvez desempenhasse algum cargo na vereação da comuna.

Como Samuel Verdugo, outros judeus castelhanos optavam pela residência em Portugal. Foi o caso de Abraão Sençarrado que obteve permissão para residir em Lisboa ${ }^{209}$. D. Afonso V concedia a José e Salomão Abudientes, naturais de Castela e estantes em Valencia de Alcántara (Cáceres) carta de segurança para poderem vir comerciar a Portugal ${ }^{210}$.

\footnotetext{
${ }^{206}$ IAN/TT, Chancelaria de D. Afonso V, liv. 9, fl. 154r.

${ }^{207}$ IAN/TT, Chancelaria de D. Afonso V, liv. 36, fl. 196v.

${ }^{208}$ IAN/TT, Chancelaria de D. Afonso V, liv. 9, fl. 94r.

${ }^{209}$ IAN/TT, Chancelaria de D. Afonso V, liv. 9, fl. 110v.

${ }^{210}$ IAN/TT, Chancelaria de D. Afonso $V$, liv. 31, fl. 18r.
} 
A aptidão para o desempenho de determinado ofício possibilitava a proximidade à corte. Foi o caso de Abraão Castelão, gibiteiro, que passou a acompanhar a corte e, por isso, recebeu o privilégio para se deslocar em mula. Para o mesmo teve a intercessão de Pedro Borges, moço da câmara do rei $^{211}$.

No último quartel do século Xv, outros judeus castelhanos optaram por residir e exercer uma profissão em Portugal. Foi o caso de mestre Salomão do Rego, natural da Galiza, e físico em Braga ou do médico rabi Moisés Guanisam (Gauison?), natural de Castela ${ }^{212}$. Noutros casos, seguia-se a voz do coração, como Ouro, judia de Ciudad Rodrigo, que viera para Portugal contra a vontade do pai para casar com rabi Sem Tob ${ }^{213}$. Ou mestre Moisés Abarrizo, cirurgião que se viera fixar com a mulher em Messejana, no Alentejo, apesar de ser filho de judeus naturais de Portugal e residentes em Beja e em Messejana. Ao obter a permissão de residência e de exercício de profissão, solicitara a autorização para vender pano de Castela a retalho no reino ${ }^{214}$, o que nos faz pressupor que continuaria a realizar frequentes deslocações a Castela ou a ter relações com produtores deste tecido.

O comércio entre os dois reinos era frequente dada a proximidade territorial e os laços familiares existentes entre os judeus dos dois lados da fronteira. Infelizmente as rotas do comércio judaico através dos portos fronteiriços e com o valor dos impostos pagos, a frequência das feiras de um e do outro reino são-nos desconhecidas. Sabemos que alguns judeus portugueses acorriam à conhecida feira de Medina del Campo e outros tinham negócios quer com a Flandres, quer com as cidades italianas, directa ou indirectamente através de parcerias com mercadores destas regiões da Europa. No entanto, se o tráfego legal nos é desconhecido, já tal não acontece com o comércio clandestino que era apanhado pelos oficiais do rei.

De facto, as relações económicas com Castela faziam-se muitas vezes clandestinamente através da fronteira e com famílias que residiam de um lado e do outro. Abraão Alufo, morador em Castelo de Vide, costumava

\footnotetext{
${ }^{211}$ IAN/TT, Chancelaria de D. Afonso $V$, liv. 10, fl. 68r.

${ }^{212}$ IAN/TT, Chancelaria de D. João II, liv. 13, fls. 37v e 91v.

${ }^{213}$ IAN/TT, Chancelaria de D. João II, liv. 4, fl. 95r.

${ }^{214}$ IAN/TT, Chancelaria de D. João II, liv. 1, fl. 48r.
} 
passar gado para o outro lado da fronteira. Um dia fora denunciado e tivera de fugir. Para conseguir o perdão real e poder voltar a residir na vila foi condenado a pagar dois justos de ouro para a arca da piedade ${ }^{215}$. Também Abraão Albarrux de Cabeço de Vide fazia contrabando de panos $\operatorname{castelhanos}^{216}$. Mestre Isaac Benadife resolvera o problema do pagamento dos impostos conluiando-se com os rendeiros da dízima e primeira sisa dos panos de Castela e nomeando-se seu parceiro indevidamente. Tal estratagema permitira-lhe meter clandestinamente no reino e em Lisboa panos que ia comprar a Castela. Acabaria por ter os seus bens confiscados a favor de João Lourenço, escudeiro do rei $^{217}$.

Haim Cohen fizera entrar em Portugal sem pagar os direitos, panos delgados de Castela e panos de Bristol, que trouxera por terra via este reino. Também ele vira os seus bens confiscados ${ }^{218}$. Luís de Melo, fidalgo da casa real, obtivera do soberano os bens de Salomão Almale, morador em Serpa, o qual recebera clandestinamente peças de Quartenay e uma peça de Menin, de Mail Almale, morador em Castela, seu irmão ${ }^{219}$. Moisés Castelão, judeu do Porto, servidor de D. Afonso V, recebia por doação régia os bens de Jacob, o rico, e Mardocai, o rico, seu irmão, confiscados para a coroa por terem metido clandestinamente panos de Castela no reino $^{220}$. O mesmo sucedera ao património de Abraão Jaen e a seu filho, residentes em Lamego acusados de transportar para Ciudad Rodrigo moedas portuguesas e aí as terem fundido juntamente com outros judeus. O beneficiado seria João de Évora, criado do bispo de Lamego ${ }^{221}$.

Arpão, judeu de Tavira (Algarve), passara indevidamente gado para Castela pelo que tivera todos os seus bens confiscados, incluindo o dinheiro da venda do gado, e dados a Bartolomeu Rodrigues, escudeiro do conde de Odemira ${ }^{222}$. Também Garcia Cide, judeu, passara para o reino

\footnotetext{
${ }^{215}$ IAN/TT, Chancelaria de D. João II, liv. 12, fls. 31v-32r.

${ }^{216}$ IAN/TT, Chancelaria de D. Afonso V, liv. 35, fl. 68v.

${ }^{217}$ IAN/TT, Chancelaria de D. Afonso V, liv. 29, fl. 93r.

${ }^{218}$ IAN/TT, Chancelaria de D. Afonso V, liv. 26, fls. 101r e 127v.

${ }^{219}$ IAN/TT, Chancelaria de D. Afonso $V$, liv. 31, fl. 6v.

${ }^{220}$ IAN/TT, Chancelaria de D. Afonso V, liv. 17, fl. 60v.

${ }^{221}$ IAN/TT, Chancelaria de D. Afonso V, liv. 17, fl. 94v.

${ }^{222}$ IAN/TT, Chancelaria de D. Afonso $V$, liv. 8, fl. 135r.
} 
vizinho trinta mil reais brancos pelo que perdera os bens que foram doados a Rui Gomes de Alvarenga ${ }^{223}$. Pela carta de perdão da fuga da prisão, concedida a José Cohen, tecelão, residente em Cabeço de Vide (Alto Alentejo), sabemos que ele e o seu irmão, Moisés, tinham sido presos em Évora por fazerem circular no reino reais de prata e espadins de ouro falsos os quais tinham recebido de Judas Abudiente, morador em Valencia de Alcántara, em pagamento do burel e outras mercadorias que este judeu lhes comprara. Provara-se a inocência de Moisés mas não a de José que, posto a tormento, acabaria por fugir da prisão. O rei perdoava-lhe a fuga mas não a razão por que fora metido na cadeia, enquanto não provasse a inocência ${ }^{224}$. Também a Castela se acolhera com a mulher, os filhos e dinheiro, Abraão Luitador, residente em Lisboa onde era sacador do serviço novo dos judeus da comuna, acusado de se ter apossado dos dinheiros e dos bens hipotecados pelos judeus que não puderam pagar o imposto ${ }^{225}$.

D. João II doava os bens de Moisés Carrião, morador em Bragança, a Moisés Crescente, espingardeiro e fabricante de pólvora de Castela, porque metera clandestinamente no reino panos de Castela ${ }^{226}$. Acusado do mesmo crime fora Moisés de Vitória, morador no Porto, enquanto outros seus parentes e vizinhos como Isaac Nunes, rabi Oce e Jacob de Vitória eram acusados de passar clandestinamente moeda para Castela ${ }^{227}$. Também Abraão e Juça de Vitória tiveram problemas com as justiças reais por terem levado moedas portuguesas para o reino vizinho e aqui as terem fundido com a colaboração de outros judeus. Os seus bens seriam confiscados no valor do resgate do fidalgo Rui de Sousa, cativo dos mouros $^{228}$. Com a mesma culpa eram presos em Olivença ou no porto de Arronches alguns judeus de Évora e rabi Oce, físico na Guarda. Para além de moedas levavam ouro, prata e outras mercadorias defesas para o reino vizinho $^{229}$. D. Diogo Coutinho recebia de D. João II os bens móveis e de

${ }^{223}$ IAN/TT, Chancelaria de D. Afonso $V$, liv. 8, fl. 104v.

${ }^{224}$ IAN/TT, Chancelaria de D. Afonso V, liv. 8, fls. 89r e 98v.

${ }^{225}$ IAN/TT, Chancelaria de D. Afonso $V$, liv. 8, fl. 69v.

${ }^{226}$ IAN/TT, Chancelaria de D. João II, liv. 4, fl. 115r.

${ }^{227}$ IAN/TT, Chancelaria de D. João II, liv. 22, fl. 107r.

${ }^{228}$ IAN/TT, Chancelaria de D. Afonso $V$, liv. 29, fl. 61v.

${ }^{229}$ IAN/TT, Chancelaria de D. João II, liv. 4, fls. 42r, 50v, 51r, 55v, 85r; liv. 8, fls. $72 \mathrm{r}, 84 \mathrm{v}, 116 \mathrm{v}, 121 \mathrm{v}$. 
raiz de Benjamim Almeradim, físico, residente em Lisboa, porquanto fizera entrar clandestinamente no reino panos, sedas e outras mercadorias defesas $^{230}$. Fernão de Espanha, escudeiro da casa real, obtivera os bens e os quatro panos de Bristol que Samuel Maçoz, residente na Guarda, metera clandestinamente no reino trazidos de Castela juntamente com cereais que aqui comprara ${ }^{231}$.

A Safra, em Castela, acolheu-se Isaías Cohen, mercador, fugido às justiças sob a acusação de ter cometido certos malefícios. No entanto, negociaria a sua reentrada no reino mediante o pagamento ao rei de mil espadins de ouro $^{232}$. Noutro caso, o perdão régio era dado contra a entrega de um judeu acusado de homicídio que se acolhera em Castela. Foi o caso de Haim Franco, culpado de ter falsificado selos reais, o qual veria a sua falta perdoada, em 1492, contra a entrega de Salomão Navarro, assassino de Toledano, que, como ele fugira para o reino vizinho ${ }^{233}$. Este Toledano, assassinado entre 1490-1492, era rendeiro principal da renda do pão, tendo como sub-rendeiro Isaac Lavança, morador em Setúbal, o qual acabaria por não conseguir entregar ao rei os dinheiros da renda, devido ao homicídio daquele. Este Isaac Toledano era irmão de Moisés Benafaçam, procurador da viúva e tutor dos sobrinhos, o qual acabaria por pagar a renda em dívida ${ }^{234}$. Outro falsificador dos selos reais foi Samuel Alegria, residente em Tavira, que se vira também obrigado a fugir do reino pelo que tivera os seus bens confiscados por D. João II $^{235}$.

Outras vezes o infractor conseguia fugir da cadeia. Tal aconteceu com o assassino de Juça Segoviano, residente em Castanheira do Rio Livre, em Trás-os-Montes. Na carta de perdão a Rodrigo Álvares, carcereiro, dada por este monarca, encontramos a menção aos perdões dos familiares da vítima: Sancho (Santo?) Segoviano, pai do morto, em nome das netas Velida e Reina de quem era tutor, Velida, mãe do morto, Cinfa, viúva, Abraão Segoviano, Belecide Segoviano, Isaac Segoviano, Rica, mulher

\footnotetext{
${ }^{230}$ IAN/TT, Chancelaria de D. João II, liv. 1, fl. 4v.

${ }^{231}$ IAN/TT, Chancelaria de D. João II, liv. 8, fld. 37r-v.

${ }^{232}$ IAN/TT, Chancelaria de D. João II, liv. 13. fl. 137r.

${ }^{233}$ IAN/TT, Chancelaria de D. João II, liv. 5, fl. 70v.

${ }^{234}$ IAN/TT, Chancelaria de D. João II, liv. 5, fl. 101r.

${ }^{235}$ IAN/TT, Chancelaria de D. João II, liv. 10, fls. 7r-v.
} 
de David Cema, irmãos e parentes do falecido e Sancho (Santo?) Aragonês, primo do morto, em seu nome e no de suas filhas ${ }^{236}$. Samuel Cordoeiro era carniceiro no concelho de Olivença, mas costumava passar clandestinamente para Castela, mais de quinhentos carneiros. Foi denunciado por uma inquirição devassa, tendo o alcaide confiscado uma parte do seu gado e ordenado que fosse colocado numa cerca. Samuel Cordoeiro para evitar perder todo o seu rebanho, recolheu os animais que conseguiu, retirou os que se encontravam na cerca e fugiu para Castela onde passou a viver. Pediu perdão ao rei porque era judeu natural de Portugal. D. João II concedeu-lhe o perdão e condenou-o a ir viver dois anos na Guarda ${ }^{237}$. Também Eleázar Tamuz, morador em Juromenha (Alentejo), era conhecido por ser passador para Castela de ouro, prata e outras mercadorias defesas pelo que tivera como recurso ir viver para o reino vizinho ${ }^{238}$.

Outras vezes era o judeu castelhano lesado por um português que era obrigado a recorrer ao rei de Portugal. José Juda, residente em Villanueva del Fresno (Badajoz), acusava junto das justiças reais Gonçalo Ramalho, morador no Redondo (Alentejo Central), por não lhe ter entregue toda a mercadoria e ainda por cima lhe batera ${ }^{239}$. Nuno Gonçalves, escudeiro, foi acusado por Abraão Baruc, judeu de Valencia, de lhe ter roubado entre outras mercadorias dinheiro ${ }^{240}$. Outro judeu castelhano, Juda, devia ter tido as suas roupas confiscadas por trazer o sinal coberto quando se dirigia a Alter do Chão. Mas os moradores do Crato que o prenderam deixaram-no ir em paz, embora o tivessem obrigado a pagar dois reais grossos de prata $^{241}$. Em Villanueva del Fresno acolhera-se Sem Tob Tobi, morador e rendeiro das sisas na vila de Alvito (Baixo Alentejo), atacado com um punhal e ameaçado pelo escudeiro João Coudo que o insultara chamando-lhe «perro, cão e renegado». Desta vila castelhana enviara a carta em que perdoava ao atacante ${ }^{242}$. Dois judeus de Badajoz foram feri-

\footnotetext{
${ }^{236}$ IAN/TT, Chancelaria de D. João II, liv. 5, fl. 89r.

${ }^{237}$ IAN/TT, Chancelaria de D. João II, liv. 27, fl. 26v.

${ }^{238}$ IAN/TT, Chancelaria de D. João II, liv. 27, fl. 83r.

${ }^{239}$ IAN/TT, Chancelaria de D. Afonso $V$, liv. 30, fl. 69v.

${ }^{240}$ IAN/TT, Chancelaria de D. Afonso $V$, liv. 8, fl. 6r.

${ }^{241}$ IAN/TT, Chancelaria de D. Afonso V, liv. 30. fl. 122v.

${ }^{242}$ IAN/TT, Chancelaria de D. Afonso V, liv. 30, fl. 150r.
} 
dos e roubados do ouro, prata, jóias e vestidos que traziam quando entraram em Portugal, cerca de 1483, por dois mancebos cristãos que seriam entregues às justiças de Marvão ${ }^{243}$.

Mais raramente era a fuga para Castela por apostasia de um converso. Moisés Soleima, morador na Guarda, recebeu as casas de Jacob, filho órfão de Menaém, que as herdara com a morte do avô e que se encontravam em poder de Fabibe, seu tutor. No entanto, Jacob convertera-se ao cristianismo e depois fugira para Castela onde regressou ao judaísmo, pelo que o rei confiscara as casas para a coroa e as doara a Moisés Soleima ${ }^{244}$.

Outros acolhiam-se aqui com medo das justiças régias. Foi o que aconteceu com um médico judeu que teve relações com cristãs. Preso, foi solto com fiança pelo que aproveitou para fugir. Mas antes convertera-se ao cristianismo adoptando o nome de António, e acolheu-se em Castela. Aqui frequentou a universidade de Salamanca onde se doutorou em medicina. Depois fora para o mosteiro de Santa María de Guadalupe de onde requereu a carta de perdão e de segurança ao rei de Portugal, a fim de poder regressar ao reino ${ }^{245}$. Ou com Samuel de Medina, morador em Évora, que se acolhera no reino vizinho depois de ter fugido da prisão por uma dívida de 10000 reais a dois judeus da comunidade, ou Abraão d'Abay que também fugira da prisão, mas de Abrantes, porque dormira com uma rapariga solteira que vivia na corte ${ }^{246}$.

\section{A InSTABILIDAdE SOCIAL, AS POLÍTICAS RÉGIAS E AS MIGRAÇÕES DOS JUDEUS PENINSULARES}

A necessidade de sentirem segurança levava a população sefardita a migrar de um reino para o outro. Aconteceu nas perturbações sociais que acompanharam a fuga de Leonor Teles para Castela e na subida ao trono de Portugal do Mestre de Avis ${ }^{247}$. Uns seguiam o seu senhor, como mestre

\footnotetext{
${ }^{243}$ IAN/TT, Chancelaria de D. João II, liv. 12, fls. 17r-v.

${ }^{244}$ IAN/TT, Estremadura, liv. 10, fl. 298v.

${ }^{245}$ IAN/TT, Chancelaria de D. Afonso $V$, liv. 35, fls. 92v-93r.

${ }^{246}$ IAN/TT, Chancelaria de D. João II, liv. 8, fls. 87v e 106r.

${ }^{247}$ IAN/TT, Chancelaria de D. João I, liv. 1, fls. 10r, 15v, 19v, 20r, 27v, 96r, etc.
} 
José, físico de D. Henrique Manuel, outros porque teriam parentes ou raízes do outro lado da fronteira como Abraão Rico, morador em Vila Flor (Trás-os-Montes), outros porque seguiam a rainha viúva recordando a protecção que o rei defunto e ela lhes tinham dado. Outros, como D. Palaçana e seu marido procuravam segurança contra a confusão que se vivia em Lisboa. Outros ainda porque a sua origem se localizava no outro lado da fronteira como Abraão Touro.

Desconhecemos a origem deste apelido Palaçano, como já referimos. A verdade é que ele iria identificar um dos grandes judeus cortesãos do século XV: Guedelha Palaçano. No início do século xv, ainda no reinado de D. João I encontramos os Gualite, os Palaçano e os Pardo ligados por laços familiares ${ }^{248}$.

Mas, apesar das perturbações sociais e de uma nova dinastia em Portugal, não aconteceram no reino os levantamentos xenófobos contra os judeus, se exceptuarmos a tentativa abortada de assalto à judiaria grande de Lisboa, em 1383, ou o assalto à mesma em 1449, prontamente reprimido pelo jovem rei D. Afonso V, apesar de aparecerem atitudes antijudaicas de índole diversas. Encontramo-las do tipo da rivalidade económica como no pedido que o concelho de Santarém requereu ao Mestre de Avis para que judeus e mouros não exercessem ofícios nem fossem rendeiros do rei. Também nos surge uma certa xenofobia de índole religiosa como a atitude, rara em Portugal, do mestre de Santiago que queria obrigar os judeus de Setúbal a assistir às pregações. Enquanto a primeira teve o beneplácito do Mestre de Avis a segunda seria prontamente proibida pelo rei D. João $\mathrm{I}^{249}$. Contudo, não esqueçamos, este não se eximiu a confirmar legislação dos monarcas anteriores sobre o uso obrigatório de sinais ou a imposição de os judeus, mesmo em trânsito, de se recolherem às judiarias, exigências requeridas pela população, nomeadamente a de Lisboa. Também legislaria sobre os tecidos que os judeus poderiam usar no seu vestuário e na sua casa, embora desconheçamos o seu conteúdo ${ }^{250}$.

\footnotetext{
${ }^{248}$ IAN/TT, Chancelaria de D. João I, liv. 4, fls. 90r-v.

${ }^{249}$ IAN/TT, Chancelaria de D. João I, liv. 1, fl. 96r.

${ }^{250}$ Lisboa, Arquivo Histórico da Casa da Moeda [= AHCM], Livro dos Pregos, docs. 245 e 248, fls. 160r e 161r; IAN/TT, Chancelaria de D. João I, liv. 5, fl. 142v.
} 
É um facto que, entre os finais do século XIV e o primeiro quartel da centúria seguinte, a população judaica aumentou, ultrapassando os espaços das velhas judiarias como aconteceu em Évora. Aqui, a judiaria era pequena o que fazia com que o preço do arrendamento das casas fosse muito elevado, obrigando muitos judeus a regressar a Castela. Por esta razão, a comuna queixava-se a D. João I sobre a necessidade de mudança de espaço ou do alargamento do já existente, o qual autorizaria uma nova localização para o espaço judaico com a permissão do concelho e dos proprietários das casas que seriam integradas na nova judiaria ${ }^{251}$. Foi nesta cidade que, em finais do século xIv, se fixou um Isaac Abravanel, como já referimos.

Nos capítulos especiais de Faro, às cortes de Évora de 1444, o concelho agravava-se do despovoamento do concelho por causa das naus que se dirigiam a Ceuta e aportavam no seu porto. Entre os que abandonavam a vila estavam os judeus que regressavam a Castela depois de venderem tudo o que possuíam. O mesmo concelho agravava-se das opressões exercidas com o direito de aposentadoria que recaíam sobre os mais pobres da vila, os judeus e os mouros, pelo que a minoria judaica abandonara a maior parte das casas da judiaria e partira para Castela ${ }^{252}$.

Mas outros judeus, apesar de residirem no reino, continuavam a ter relações estreitas em Castela que lhes permitiam servir o rei de Portugal e serem agraciados por esse serviço. Fora o caso de Isaac Latam que representara D. Afonso V em Castela, quando pretendente ao trono como marido de D. Juana. Aliás, o privilégio concedido era em pagamento dos serviços prestados no reino de Castela ${ }^{253}$. Desconhecemos a proveniência desta família que é referida na correspondência da chancelaria já ligada à corte, como era o caso de Moisés Latam, pai daquele, e alfaiate do rei. Este era com os Abravanel, Palaçano, credor do rei, tendo emprestado ducados a D. Afonso V para o doutor João Fernandes da Silveira gastar na corte de Roma ${ }^{254}$. Também um Marracoxim, alfaiate do rei, recebia o privilégio de vizinho de Évora e de todo o concelho em que viesse a re-

\footnotetext{
${ }^{251}$ IAN/TT, Chancelaria de D. João I, liv. 3, fl. 85r.

${ }^{252}$ IAN/TT, Chancelaria de D. Afonso V, liv. 24, fls. 53r-v; Odiana, liv. 4, fl. $242 \mathrm{v}$.

${ }^{253}$ IAN/TT, Chancelaria de D. João II, liv. 11, fls. 62r-v.

${ }^{254}$ IAN/TT, Chancelaria de D. Afonso $V$, liv. 1, fl. 2r.
} 
sidir, isenção de porte de sinal, do pagamento dos impostos pagos pelos judeus à coroa e permissão para trazer armas consigo, em pagamento de serviços prestados no reino, em Castela e em África ${ }^{255}$. Certamente, serviços prestados fizeram $\mathrm{D}$. Afonso $\mathrm{V}$ esquecer que abolira o cargo de arrabi mor, ainda no tempo de mestre Abraão Negro, e nomeara em Toro um mestre Abas, rabi mor de Portugal, com a tença de 4000 reais a partir de $1476^{256}$, judeu cuja família nos é desconhecida. Seria o mestre Abas, físico do duque de Bragança, em 1478? Este fora aperfilhado por mestre Mail Abenafaim e Dona Formosa, judeus de Ourém, para poder herdar todos os seus bens em detrimento dos herdeiros legais ${ }^{257}$.

Mas outros aproveitavam as pretensões do rei português ao trono castelhano para regressarem a Castela. Fora o caso de José Savarigo, judeu português, residente em Moura que foi viver para Castela sem permissão do rei, pelo que tivera os bens confiscados para a coroa e doados a Pedro de Moura, fidalgo do conselho régio ${ }^{258}$.

Neste último quartel do século XV, a imigração dos judeus castelhanos começava a pesar socialmente, fazendo aumentar a população judaica que extravasava em algumas judiarias para arruamentos ocupados pelos cristãos. Noutros casos era o povoamento de concelhos fronteiriços que levava D. João II a privilegiar os judeus que fossem habitar em Bragança no interior da cerca para que ela fosse bem povoada. O mesmo se passou com Chaves ${ }^{259}$. Mas não eram apenas estas judiarias que tinham necessidade de alargar a sua área. O mesmo se passava com as sinagogas tornadas pequenas para receber a população que nelas ia rezar. Foi o caso de Lisboa, de Torres Novas, do Mogadoiro, Trancoso, entre muitas outras. Estávamos em $1481^{260}$. As migrações ocorriam por razões económicas e religiosas mas também por razões familiares. Abraão Cabanas, natural de San Felices de los Gallegos (Salamanca),

${ }^{255}$ IAN/TT, Chancelaria de D. Afonso V, liv. 9, fl. 13r.

${ }^{256}$ IAN/TT, Chancelaria de D. Afonso V, liv. 7, fl. 3v.

${ }^{257}$ IAN/TT, Estremadura, liv. 10, fls. 194r-v.

${ }^{258}$ IAN/TT, Chancelaria de D. Afonso $V$, liv. 7, fl. 27v.

${ }^{259}$ IAN/TT, Chancelaria de D. João II, liv. 19, fl. 81v.

${ }^{260}$ IAN/TT, Chancelaria de D. Afonso V, liv. 26, fls. 26v, 79v, 135v; Chancelaria de D. João II, liv. 2, fl. 131r. 
pedia autorização para vir residir em Portugal e exercer a arte da medicina, porquanto estava esposado com uma judia de Gouveia. A permissão para o exercício da profissão foi-lhe dada depois de ter obtido aprovação no exame da arte, tendo como examinador mestre Rodrigo, físico mor do reino ${ }^{261}$.

O clima contra os castelhanos, fossem judeus ou conversos, degradou-se no final da década de 80 do século xv. Desconfiava-se de hereges criptojudaicos e do apelo à apostasia dos conversos por parte de alguns judeus o que gerava movimentos xenófobos contra os recém chegados castelhanos que entravam a pouco e pouco em Portugal. Em 1486, um alvará de D. João II dirigido à câmara de Lisboa estranhava o transporte clandestino de judeus castelhanos (e?) conversos para Mazagão e outras partes da Berbéria em barcos saídos deste porto que, em terras de mouros, se tornavam judeus ${ }^{262}$. Por ter passado para o norte de África «marranos» com ouro, prata e mercadorias, sem autorização régia, Álvaro Fernandes, mestre e dono da caravela do Caeiro, tivera os seus bens confiscados. O mesmo acontecera com os bens e as caravelas de outros mestres e proprietários de caravelas, acusados de levarem conversos castelhanos para o norte de África, o que era contra as leis do reino ${ }^{263}$.

Também Estêvão de Sequeira e João Dias, respectivamente capitão e mestre de uma caravela que a Casa da Mina enviara a África, foram acusados de transportarem clandestinamente a mulher, os filhos e uma irmã de Pedro de Luna os quais iam tornar-se judeus em terras de mouros. Pela viagem, estes conversos castelhanos tinham pago 70 cruzados de ouro, metade para cada um deles ${ }^{264}$. Outros tiveram mais sorte, mas viram os bens confiscados quando foi descoberta a sua fuga e a consequente apostasia. Foi o caso de João de Medina, Rodrigo, seu filho, Pedro Fernandes e Pedro Álvares, genros daquele, que partiram para o norte de África onde tornaram ao judaísmo ${ }^{265}$.

${ }^{261}$ IAN/TT, Chancelaria de D. João II, liv. 25, fl. 66r.

${ }^{262}$ Lisboa, AHCM, Livro dos Pregos, doc. 453, fl. 275r.

${ }^{263}$ IAN/TT, Chancelaria de D. João II, liv. 1, fls. 108v-109r; liv. 4, fl. 26r; liv. 21, fl. $73 \mathrm{v}$.

${ }^{264}$ IAN/TT, Chancelaria de D. João II, liv. 8, fl. 36v.

${ }^{265}$ IAN/TT, Chancelaria de D. João II, liv. 8, fl. 87v. 
Em 1485, o rabi Jacob Galite de Lisboa teve problemas com as justiças porque uma jovem castelhana chegara a esta cidade e dirigira-se às autoridades comunais para pedir licença para casar com um judeu castelhano que para aqui viera residir. O rabi recusara, alegando que não era «serviço de Deus» o casamento entre ambos. Foi o suficiente para crescerem as suspeitas de que a jovem era conversa e que o rabi não a entregara às justiças ${ }^{266}$.

Noutros casos, assistiu-se à tentativa de converter ao judaísmo conversos entrados em Portugal que acabavam condenados por apostasia. Foi o caso de um João de Niébla queimado em Santarém por judaísmo que acusara um Rondim, ourives, de o ter aliciado a estar presente a uma celebração da Páscoa das Cabanas e ter aceite dinheiro para o azeite da sinagoga quando o recebera em sua casa. O mesmo acusara Moisés Mourisco, morador em Santarém, de ter recebido dele esmola para a sinagoga ${ }^{267}$.

Estávamos em 1488 e a entrada de conversos que fugiam à Inquisição espanhola, misturados com alguns judeus tornara-se uma realidade no quotidiano português. Tal se nos configura o caso de José Geste, sapateiro, castelhano, estante em Évora que fora ferido numa rixa por Haim Orta, o moço, sapateiro também o qual lhe emprestara um calçador que aquele se recusara a entregar ${ }^{268}$. Ou o de Moisés Franco, casado em Valladolid, que, em Portugal, passara a viver maritalmente com Estrela pelo que fora preso por bígamo. Seria libertado depois de dar carta de divórcio à antiga mulher que permanecia em Castela ${ }^{269}$.

Alguns deles procuravam ir mais além do território nacional continental. A Madeira e o seu açúcar era um local desejado pelos conversos, até porque se sentiam seguros, longe da suspeição do povo, da Igreja e dos oficiais do rei. No entanto, em Março de 1490, D. João II ordenava que os conversos castelhanos abandonassem a ilha com famílias e bens, até Setembro deste ano. Apenas lhes ficava reservada a deslocação à ilha por períodos curtos para negociarem, os quais não deveriam ultrapassar os três meses de permanência ${ }^{270}$.

\footnotetext{
${ }^{266}$ IAN/TT, Chancelaria de D. João II, liv. 8, fl. 66v.

${ }^{267}$ IAN/TT, Chancelaria de D. João II, liv. 15, fls. 36v, 42r.

${ }^{268}$ IAN/TT, Chancelaria de D. João II, liv. 16, fl. 65v.

${ }^{269}$ IAN/TT, Chancelaria de D. João II, liv. 16. fl. 115v.

${ }^{270}$ F. A. J. Pereira Rodrigues, Alguns elementos para o estudo da história económica
} 
Apesar do clima social antijudaico ameaçar agudizar-se, D. João II, ainda em finais de 1491, pensava povoar Chaves com famílias judaicas e incentivava ao povoamento e acrescentamento da judiaria do concelho, concedendo privilégios fiscais durante dez anos a partir daquela data a todos quantos nele se fixassem ${ }^{271}$. Noutros casos a instabilidade social fazia-se sentir no interior das comunas, devido à rejeição da autoridade comunal portuguesa por parte dos judeus castelhanos. Fora $o$ caso que ocorrera no Alandroal (Alentejo Central), mas também noutros locais, que levara Juda Negrim, judeu castelhano, à prisão por ordem do rabi Jacob Galite que o acusara de desobediência e de desrespeito porquanto aquele afirmara que «não prezava os seus mandatos porque era castelhano» ${ }^{272}$.

O descontrolo social era visível, devido às imigrações desregradas de judeus e conversos castelhanos. Ainda, em 1498, já após a conversão forçada da minoria, os conversos ou confessos continuariam a ser apontados pela sociedade cristã velha. Nos capítulos de Évora, queixavam-se dos carvoeiros vindos de Castela que destruíam os coutos dos azinhais ${ }^{273}$.

\section{As eXPulsões dos Judeus da Península e as novas migrações}

A 31 de Março de 1492, os reis Isabel e Fernando publicavam o édito de expulsão da minoria judaica do reino. A sua saída era obrigatória até ao fim de Julho desse ano, ou seja, num muito curto prazo de tempo ${ }^{274}$. Isto significava a desvalorização dos bens dos judeus e a sua venda ao desbarato, assim como a perda real dos investimentos feitos nas rendas régias e outros direitos, ou nos empréstimos concedidos a cristãos. Os prejuízos foram grandes e poucos devem ter conseguido abandonar Castela e Aragón com os problemas resolvidos, tanto mais que lhes era interdito levar para o exterior metais preciosos e moedas, cereais, animais, armas, pólvo-

da Madeira (capitania do Funchal, século XV) (Coimbra, 1959, tese dactilografada), CXVII (doc. 37).

${ }^{271}$ IAN/TT, Chancelaria de D. João II, liv. 11, fls. 64v-65r.

${ }^{272}$ IAN/TT, Chancelaria de D. João II, liv. 14, fl. 105r.

${ }^{273}$ IAN/TT, Odiana, liv. 1, fl. 236r.

${ }^{274}$ SuÁrez FernándeZ, Documentos acerca de la expulsión, 391-395 (doc. 177). 
ra e outras mercadorias proibidas, para além serem obrigados a justificar que não tinham sido usurários os empréstimos feitos a cristãos ${ }^{275}$.

Perante tais dificuldades, era óbvio que o baptismo era uma maneira de permanecerem no reino mais algum tempo de modo a poderem solucionar com melhores resultados a venda dos seus bens e, mais tarde, poderem sair do reino. Tal hipótese deve ter-se colocado às comunidades judaicas de Maqueda e Torrijos (Toledo), como se colocou a Antão Rodrigues, vizinho de Herrera de Pisuerga (Palencia), que se fez baptizar enquanto os pais judeus e outros seus parentes partiram deixando alguns bens imóveis, como casas, vinhas e terras na referida vila e seu termo os quais acabaria por herdar como legítimo sucessor que era destes seus parentes até ao terceiro grau, não sem que tivesse tido necessidade de litigar os bens paternos e os dos seus parentes junto dos soberanos contra o condestável de Castela. Não seria o único a converter-se ${ }^{276}$.

Perante a inevitabilidade de expatriação, os judeus castelhanos procuraram encontrar acolhimento em Portugal. Uma embaixada encabeçada por Isaac Aboab e Abraão Zacuto teria sido recebida por D. João II. Desta reunião ficou decidida a permanência de uns no reino, as seiscentas casas, e de livre trânsito para a maioria que deveria partir por mar, em barcos fornecidos pelo rei, para os reinos mediterrânicos. Nápoles seria um dos destinos para os que partiam por mar.

Em direcção a Portugal, os judeus castelhanos saíram por Fresno de los Ajos e Ciudad Rodrigo cujas autoridades lhes exigiram abusivamente novas imposições fiscais para lhes permitirem a saída do reino ${ }^{277}$, em direcção aos portos fronteiriços da Beira, certamente Vilar Formoso. Outros saíram por Zamora, sendo também indevidamente taxados num lugar entre Abóbada e Zamora ${ }^{278}$. Iriam entrar em Portugal por Bragança ou Miranda. Outros abandonavam Castela por Badajoz e entravam por Marvão e Castelo de Vide, onde ainda hoje o lugar da Portagem recorda um dos locais de entrada e de pagamento do imposto requerido pelo rei de Portugal.

275 SuÁREz Fernández, Documentos acerca de la expulsión, 413-419, 422-423, 428432, 442-450 (docs. 187, 188, 189, 191, 193, 197, 198, 206, 207, 208, 209, etc.).

276 SuÁREZ FERnÁNDEZ, Documentos acerca de la expulsión, 454-456, 459-461, 468470 (docs. 213, 216, 221, 222).

277 SuÁrez FERnÁndez, Documentos acerca de la expulsión, 451-453 (doc. 211).

${ }^{278}$ SuÁrez FERnÁNDEZ, Documentos acerca de la expulsión, 464-465 (doc. 219). 
Quantos eram, é-nos difícil dizer. Sabemos que os das seiscentas casas pagavam 8 cruzados per capita e os ferreiros e armeiros metade. Eram os que tinham permissão de D. João II para permanecer no reino e seriam distribuídos por Lisboa, Porto, Évora e Coimbra. Os restantes, embora fossem obrigados a pagar os 8 cruzados, deviam usar o território como mero local de passagem para outras cidades na Europa mediterrânica, devendo abandonar o reino pelos portos que o monarca lhes viria a definir.

Pelas cartas de quitação dadas por D. Manuel, sabemos que Afonso Vaz foi o recebedor dos tributos pagos pelos judeus castelhanos entrados pelo porto de Marvão, em dinheiro e $\operatorname{panos}^{279}$. Por sua vez, Lopo de Reboredo recebera o dinheiro, os panos e outras mercadorias com que os judeus entrados pelos portos de Miranda e Bragança pagaram a sua entrada em Portugal ${ }^{280}$. Não vamos discutir o número dos recém-vindos. Apenas podemos confirmar que foram suficientes para duplicar, no mínimo, a população judaica natural do reino.

O pagamento em dinheiro e outras mercadorias proibidas seria objecto de inquirições várias por parte dos reis de Castela e Aragón, as quais marcariam todo o segundo semestre de 1492 e ainda o ano seguinte, porquanto estavam interditos no édito de expulsão. De facto, os soberanos não aceitavam esta transgressão e ordenavam inquirições nos portos por onde se suspeitava que os judeus tinham saído com os bens proibidos. Pelo relatório de Fernando Gomez e de Fernando Suarez, sabemos que San Felices de los Gallegos, Puebla de Sanabria e Ciudad Rodrigo tinham sido uns desses locais. E acrescentavam, segundo a informação do licenciado Vargas, que pelos caminhos para Portugal «há indícios de que passou muito dinheiro». E informavam também os monarcas que os judeus tinham encontrado coniventes para o transporte clandestino do dinheiro para Portugal, como o comendador de Castrotorafe, o conde D. Afonso e D. João Henriques, alcaides e oficiais da Estremadura «passaram e consentiram passar muita moeda e ouro e prata de judeus» ${ }^{281}$. O bispado de Badajoz e o território do mestrado de Alcántara sofreriam idêntica inves-

${ }^{279}$ A. Braamcamp Freire, «Cartas de quitação de D. Manuel», Archivo Histórico Portuguez XI (1918), 205 (doc. 27).

${ }^{280}$ A. Braamcamp FreIre, «Cartas de quitação de D. Manuel», Archivo Histórico Portuguez IV (1906), 287 (doc. 452).

${ }^{281}$ SuÁrez FernándeZ, Documentos acerca de la expulsión, 499-501 (doc. 240). 
tigação ${ }^{282}$. Os judeus provenientes da Galiza, nomeadamente de Coruña, Villafranca (del Bierzo), Ferrol, Pontedeume e «Lisbona» [sic?], partiram por mar com ouro, prata e pérolas para o norte de África ${ }^{283}$, embora fosse provável que tivessem passado a fronteira do norte de Portugal, apesar de desconhecermos o local de entrada.

Mas muitos mais infiltraram-se clandestinamente ou não tiveram dinheiro para pagar a estadia ou o trânsito, pelo que o soberano os iria convidar à conversão pela lei de 19 de Outubro de 1492, ou forçá-los a aceitar o baptismo, retirando-lhes os filhos menores que fez baptizar e entregou a Álvaro de Caminha, capitão de S. Tomé, para os educar cristãmente e dar-lhes uma participação na produção e exploração do açúcar nesta ilha ${ }^{284}$. Outros que não aceitaram a conversão nem conseguiram ser resgatados pelos judeus portugueses nem partir foram tornados escravos e só alcançariam a liberdade com a subida ao trono de D. Manuel, em Outubro de 1495. Com eles entrou também a peste o que fez ainda mais exaltar os ânimos ${ }^{285}$.

Em Novembro, eram os próprios Reis Católicos a reconhecer o desejo de muitos judeus regressarem a Castela, outorgando para o efeito carta de segurança aos judeus que se convertiam na fronteira, quer do lado castelhano quer do lado português, e desejavam regressar ao solo pátrio e aos seus bens. Para o efeito determinava os locais de entrada que deviam coincidir com os portos de saída. Assim, para os que saíram por Ciudad Rodrigo deviam receber o baptismo nesta cidade, o mesmo sucedendo aos que partiram por Zamora e Badajoz que deviam ser baptizados pelos bispos destas duas cidades ${ }^{286}$. Tal sucedeu com D. Çag Abuacar, físico, e outros judeus e judias que pretendiam regressar a Castela e fazer-se baptizar, assim como recuperar os bens que tinham vendido a cristãos pagando-lhes o seu valor. Os reis concediam-lhes permissão devendo converter-se em Portugal ou no primeiro lugar cristão do reino

${ }^{282}$ SuÁrez Fernández, Documentos acerca de la expulsión, 523-524 (doc. 256).

${ }^{283}$ SuÁrez Fernández, Documentos acerca de la expulsión, 513-514 (doc. 249).

${ }^{284}$ IAN/TT, Corpo Cronológico, Parte III, maço 1, $\mathrm{n}^{\circ} 34$.

${ }^{285}$ Sobre a perspectiva portuguesa, veja-se: TAvares, Os Judeus em Portugal no século XV, vol. II, 256-257 e 427-430; M ${ }^{\mathrm{a}}$ J. Ferro TAVARES, Judaísmo e Inquisição. Estudos (Lisboa: ed. Presença, 1987), 23-25.

${ }^{286}$ SuÁrez FernándeZ, Documentos acerca de la expulsión, 487-489 (doc. 231). 
de Castela ${ }^{287}$. Ou com Juda Corcos, filho de Abraão Corcos, e a sua família, naturais de Zamora que abandonaram o reino levando consigo muito ouro, prata, jóias e moedas, os quais requeriam o perdão real e pretendiam regressar baptizados a esta cidade e aos seus bens. Os reis autorizavam o regresso, desde que se fizessem baptizar na cidade por onde partiram, ou seja, Badajoz, Ciudad Rodrigo ou Zamora ${ }^{288}$.

Na corte portuguesa ficou rabi Abraão Zacuto, «estrolião», contemplado em Junho de 1493 com a doação régia de 10 espadins de ouro ${ }^{289}$. Ao rei interessava-lhe possuir mais um conhecedor de astrologia e autor das tábuas de declinação solar, embora tivesse a seu lado o médico e astrólogo mestre José Vizinho a quem incumbiria a tradução da obra de Zacuto do hebraico para linguagem. Na obra em língua castelhana, editada pelos Ortas na tipografia de Leiria, mestre José apresentar-se-ia como discípulo de Zacuto. Infelizmente muito pouco se sabe sobre a presença de Zacuto no reino e na corte. Curiosamente, envolvido na política de informações sobre o Oriente temos um rabi Abraão de Beja, um homónimo do físico do duque D. Manuel, mestre Abraão e que, provavelmente, seria mestre Abraão físico da infanta D. Beatriz ${ }^{290}$. Não cremos poder associar os dois rabis, apesar de conhecermos a ligação do então duque D. Manuel à astrologia e a rabi Abraão, provavelmente Zacuto.

Para o Porto teriam ido 30 «casas» que se instalaram na Rua de S. Miguel. Eram encabeçados por Isaac Aboab, o «último gaon» de Castela. Seriam cerca de duas centenas de pessoas. Entre estas estava a família deste rabi, como Abraão (?) Aboab, avô de Emanuel Aboab, autor da Nomologia ${ }^{291}$.

${ }^{287}$ SuÁREZ FernÁNDEZ, Documentos acerca de la expulsión, 504-505 (doc. 242).

${ }^{288}$ SuÁrez Fernández, Documentos acerca de la expulsión, 520-522 (doc. 254).

${ }^{289}$ IAN/TT, Corpo Cronológico, Parte I, maço 2, doc. 18. Sem querer entrar em polémica com os hebraístas (entre os quais o meu marido e o Dr. J. Castaño), não posso deixar de mencionar a transliteração portuguesa do nome Zacuto que nos séculos XV e XVI se escrevia «Çacoto» ou «Çacuto», o que não era de estranhar se nos lembrarmos que Zamora se escrevia Çamora. Exemplo daquela transliteração é Gaspar Correia nas Lendas da Índia, para não mencionarmos os Abraão Çacuto da chancelaria real. Gaspar Correia transliterou também na forma «Caçuto» (G. CorreiA, Lendas da Índia [Porto: Lello \& Irmão, 1975], vol. I, 10, 16, 23 e 261-265).

${ }^{290}$ IAN/TT, Chancelaria de D. João II, liv. 16, fls. 8r-v; liv. 21, fl. 139r.

${ }^{291}$ Imanuel АвОАВ, Nomologia o Discursos Legales (Amesterdão, 1629), 299-300. 
Santarém e Évora receberam um certo número de famílias. Na cidade alentejana, os judeus castelhanos não couberam nas casas da judiaria e tiveram de ser alojados em casas de cristãos. Em Santarém, procuraram integrar-se na comunidade judaica e no concelho. Um dos actos que conseguiram, embora em vésperas da expulsão, foi a autorização para a criação de uma estalagem para acolher 400 viandantes e dar aposentadoria aos oficiais do rei e membros da casa real com categoria de escudeiros, que a ela tivessem direito e aí fossem colocados pelo contador da aposentadoria da câmara de Santarém. A proprietária era uma judia, Cinfa, talvez castelhana, mulher de Samuel Carpalho e o contrato com o concelho obrigava-a a manter as 400 camas durante dez anos, em troca de cento e vinte mil reais/ano. O contrato teria início em Janeiro de 1497 . No caso de Cinfa falhar o contrato, a responsabilidade da sua manutenção caberia à comuna. Entre as testemunhas, como representantes da comuna de Santarém, encontramos o «raby David Cheerell e Barzalay Baur e Yuda Carecem, solteiro, todos judeus castelhanos estantes nesta villa» ${ }^{292}$.

Espalharam-se pelo reino, nomeadamente pelas cidades portos de saída ou noutras onde as comunidades eram grandes, como Évora ou Lisboa. Esta, em Março de 1493, recebia um agradecimento público pelo modo como acolhera os judeus castelhanos, tanto mais que a corte estava fora da cidade por causa da peste. Entre estes encontrava-se o físico castelhano D. Samuel a quem o monarca pedia à cidade que o deixasse entrar e exercer aqui o seu ofício. Outros que obtiveram a mesma permissão para nela residirem com a sua família foram Mail Sornaga que iria trabalhar na Casa da Moeda e um outro judeu castelhano que era tangedor. Este último obtivera a intercessão de D. Jorge, filho bastardo de D. João II ${ }^{293}$. Sabemos que a coroa recebeu 8390220 reais dos judeus castelhanos que ficaram em Lisboa ${ }^{294}$, o que se supusermos ter sido o equivalente à capitação dos 8 cruzados daria um pagamento feito por cerca de 23000 judeus. Menos agradado teria ficado o rei pelo comportamento do concelho do Porto que considerou ter sido negligente na sua actuação ${ }^{295}$.

\footnotetext{
${ }^{292}$ As Gavetas da Torre do Tombo IV (Lisboa: Centro de Estudos Históricos Ultramarinos, 1964), 189-193: 192.

${ }^{293}$ Lisboa, AHCM, Livro $3^{\circ}$ de D. João II, docs. 52, 57, 62 e 64.

${ }^{294}$ IAN/TT, Estremadura, liv. 2, fl. 223v.

${ }^{295}$ Porto, AHCM, Livro Antigo de Provisões, doc. 204, fl. 84.
} 
Com os judeus castelhanos veio uma riqueza incalculável em livros que, mais tarde, D. Manuel confiscaria. Na armada do vice-rei D. Francisco de Almeida, o filho do corregedor Martim Pinheiro levaria uma arca cheia de livros e bíblias hebraicas para vender em Cochim, no que viria a ser proibido pelo vice-rei ${ }^{296}$.

Um dos portos de saída era Setúbal. Nos seus arredores, junto aos Poços, foi levantado um acampamento para os acolher. Aqui faleceria D. Sag Allalbo, natural de Piedrahita (Ávila) ${ }^{297}$.

D. Manuel, a 4 de Dezembro de 1496, ordenava a expulsão dos judeus residentes no reino. Deveriam sair até Setembro do ano seguinte ou aceitar o baptismo. O baptismo forçado obedeceu a várias fases: a conversão voluntária com consequentes privilégios régios, o baptismo das crianças retiradas aos pais judeus e entregues a famílias cristãs que as criaram e o baptismo dos adultos, vulgarmente conhecido pelo baptismo dos «Estaus» em Lisboa ou dos baptizados de pé, mas que ocorreu nas igrejas de todo o reino. Este baptismo forçado e independentemente da forma como ocorreu apanhou também os judeus castelhanos que se encontravam em Portugal. Tal como aconteceu com os judeus portugueses a quem o soberano integraria na pequena nobreza, como, por exemplo, o escudeiro João Fernandes ( $\mathrm{ol}$. Gota), residente em Santarém ${ }^{298}$, ou o cavaleiro Jorge Oliveira (ol. Bixorda), ou o escudeiro João Rodrigues de Mascarenhas.

Com o baptismo, não se alterou a relação entre a coroa e os agora cristãos novos. Estes continuaram a ser cortesãos, quer como médicos da família real, quer como financeiros da expansão portuguesa ou da corte. Um deles foi João Rodrigues Mascarenhas, escudeiro, assassinado em Abril de 1506, que trouxe arrendados os negócios do rio da Gâmbia e o trato de Cantor nos anos de 1501 e 1502, para além de continuar com as moradias reais, o açúcar da Madeira e a vintena da Guinée ${ }^{299}$. Foi parceiro

${ }^{296}$ CoRreia, Lendas da Índia, vol. I, 656-657.

${ }^{297}$ IAN/TT, Inquisição de Évora, no 4292 (Gabriel de Fontes).

${ }^{298}$ IAN/TT, Casa de Santa Iria, Caixa 6, no 82 (documento gentilmente cedido pelo Dr. Pedro Pinto, a quem agradeço). Neste documento, datado de 5 de Dezembro de 1499 , encontram-se referências a Tristão de Oliveira, ol. Samaia, que era o herdeiro de Judas Usque, numa casa junto à torre do relógio de Santarém.

${ }^{299}$ Freire, «Cartas de quitação de D. Manuel», Archivo Histórico Portuguez IV (1906), 72-73 (docs. 413-417). Mantive a grafia do apelido judaico, aqui usado como 
de Fernão de Loronha na exploração do litoral brasileiro, mas infelizmente não conseguimos identificar o judeu mais odiado pelo povo de Lisboa, nem os seus parceiros. Um deles era Jorge de Oliveira que conhecemos pela alcunha de Bixorda, o apelido judaico de uma família de Lisboa e que seria feito escudeiro e depois cavaleiro por D. Manuel.

Os cristãos novos cortesãos desempenhavam as mesmas funções dos judeus que serviam na corte. Aliás, não houve qualquer ruptura, até porque muitos deles abraçaram voluntariamente o baptismo. Eram médicos, financeiros, rendeiros e tratadores das moradias e das tenças reais. Estavam ao serviço do soberano e da família real. Alguns auferiam tenças do rei como Gonçalo Mendes Çacoto que, em 1512, recebia 12000 reais de tença ${ }^{300}$.

Após o baptismo forçado dos judeus portugueses e castelhanos, encontramos a menção a alguns médicos castelhanos que aqui permaneceram, como mestre Tomás da Paz, físico castelhano, morador em Elvas, mestre Henrique de Sevilha, residente em Vila Viçosa, examinado em cirurgia em 1496, mestre António, castelhano que se estabelecera em Nisa, mestre João, físico na Vidigueira, mestre Jerónimo, cirurgião em Avis, mestre Inigo de Ribas Altas, cirurgião no Porto, entre outros ${ }^{301}$. O baptismo foi um meio que muitos procuraram para se poderem movimentar na Península e, eventualmente, saírem dela para regressar à religião dos seus antepassados em liberdade. Tal aconteceu com Samuel Ruben e Amada Belhamin, sua mulher, moradores em Loulé, que partiram para Jerez de la Frontera, deixando as casas como dote ao genro Fernão Luís que as venderia e partiria para o reino vizinho. $\mathrm{O}$ objectivo era partir para terra de mouros onde se tornariam judeus. Não obteriam sucesso na viagem pelo que foram presos e queimados por hereges em Castela $^{302}$.

Mas, apesar do baptismo, a circulação, quer no reino, quer para fora dele, era muito limitada e sempre objecto de aprovação régia, mesmo após 1506,

alcunha, tal como se encontra na documentação coeva e que Braamcamp Freire transcreveu literalmente. Será a mesma grafia que o cronista Gaspar Correia utiliza para identificar o astrónomo Zacuto.

${ }^{300}$ A. Braamcamp Freire, «Os cadernos dos assentamentos», Archivo Histórico Portuguez VII (1909), 376.

${ }^{301}$ IAN/TT, Chancelaria de D. Manuel, liv. 14, fls. 67r, 74v; liv. 2, fls. 4r, 8v, 25v, $45 r$, etc.

${ }^{302}$ IAN/TT, Chancelaria de D. Manuel, liv. 6, fl. 24v. 
ano do levantamento e massacre contra os cristãos novos de Lisboa. Vejamos alguns exemplos da presença dos agora cristãos novos de origem castelhana em Portugal e dos percursos que seguiram até que se fixaram num local.

Um deles foi Rodrigo Eanes, o Caldeirão (ol. Juda), natural de Maqueda, sapateiro de profissão. Estava casado com Leonor Gomes e tinha deste casamento oito filhos adultos vivos na altura em que foi preso. De Maque$\mathrm{da}$, onde nascera, fora viver com os pais em Badajoz. Entraram em Portugal por altura do desterro dos judeus de Castela. O pai chamara-se em judeu Natan. Era trabalhador rural. Baptizados em Elvas, os pais tomaram o nome de Pedro Caldeirão e de Catarina Eanes, a Caldeiroa. Rodrigo, então, criança de oito anos de idade, fora retirado aos pais e baptizado em Santa Maria dos Açougues, em Elvas. Este baptismo das crianças ocorrera no reinado de D. Manuel e não no de D. João II, como ele referiria por engano ${ }^{303}$. Daqui a família regressaria a Badajoz, onde Rodrigo Eanes viria a casar com Leonor Gomes. Aqui viveram alguns anos, antes de voltar de novo para Portugal e terem-se fixado em Elvas. Nesta cidade, viria a envolver-se numa escaramuça popular, acabando por matar um homem, pelo que se acolheu, de novo, com a mulher e os filhos pequenos na cidade de Badajoz, habitando na rua que ia das carniçarias para a Praça. Só regressariam a Portugal, depois de obtido o perdão do rei, tendo vindo viver para Arronches. Entretanto os pais já tinham falecido e estavam sepultados em Elvas, ele na igreja de S. Lourenço, e ela na igreja da Madalena.

Confessaria que viera para Portugal com medo da Inquisição, porque vira prender muitos cristãos novos na cidade. O inquisidor perguntar-lhe-ia se sabia que tinha sido queimado em estátua e que o seu sambenito se encontrava exposto na igreja de S. João de Badajoz, juntamente com os dos outros cristãos novos entregues à justiça secular. Rodrigo Eanes confirmaria que tomara conhecimento por um dos presos, Diogo Lopes Valeiro, que saíra reconciliado, e lhe confessara tê-lo denunciado porque ele se encontrava já em Portugal com a família. Diogo Lopes viera viver para Portugal, para Alcácer, onde já se encontravam a morar os seus irmãos. Também o denunciara em Llerena o sapateiro Francisco Gomes,

${ }^{303} \mathrm{O}$ baptismo das crianças e o seu confisco aos pais judeus, ocorrido no reinado de D. João II, levaria estas crianças para S. Tomé. Não nos consta que tivesse havido outra medida semelhante sobre as crianças judias no governo deste monarca, permitindo-lhes ficar no reino baptizadas e a ser criadas por famílias cristãs. Também, muito provavelmente, não fora baptizado com 8 anos, se declarava ter 60 em 1546, e ter sido judeu. 
castelhano como ele, o qual tinha a mulher presa em Évora. Acrescentava que vivera com a família em Badajoz na altura em que constava que por lá andava o Judeu do Sapato, David (Reubeni).

A menção a este nome por parte de Rodrigo Eanes atiçara a curiosidade do inquisidor que quis saber o que constava em Badajoz sobre este judeu e a sua família. Respondera que era «rei e filho de rei» e viera a Portugal e a Castela para bem dos cristãos novos e para os conduzir a outras paragens. Acrescentava não ter conhecimento de mais nada. Apesar de baptizado, continuara a seguir a Lei de Moisés, guardando o sábado, a Pessah, comendo o pão ázimo que a mulher cozinhava em casa em forma de bolos redondos com umas dedadas por cima como enfeite durante toda a semana, jejuando o Yom quipur, o Thisabeat, o jejum da Rainha Ester e os outros jejuns da Lei. Possuía um reportório que lhe fora dado pelo pai, por onde sabia as luas e quando caíam as diversas festas e jejuns. Seria convidado a abjurar os seus erros, beneficiando do perdão geral dado aos cristãos novos portugueses em $1547^{304}$.

Impossibilitados de abandonar o reino para outras zonas da cristandade, os judeus castelhanos, tal como os portugueses, foram apanhados no jogo político entre os Reis Católicos e D. Manuel I. Eles foram os peões, destinados a abater, no desejo deste casar com a princesa viúva Isabel e na pressão imposta por aqueles: a filha só seria rainha de Portugal se os judeus e os conversos saíssem do reino que os acolhera. Perante a obrigatoriedade de receberem o baptismo ou de emigrarem, novamente, os judeus castelhanos, ainda sem local fixo para residirem, movimentavam-se no reino. André Gonçalves, sapateiro, natural de San Felices de los Gallegos, recebia o baptismo de pé na igreja de Santa Marinha, perto do Porto, antes de se fixar em Trancoso. Já Ana Rodrigues, oriunda de Medina del Campo, seria baptizada na igreja de S. João de Vila Nova de Trancoso, onde casaria e ficaria a residir. Rui Vaz, natural de Valencia de Alcántara fora baptizado em Cabeço de Vide $^{305}$.

${ }^{304}$ IAN/TT, Inquisição de Évora, no 9879 (Rodrigo Eanes, 1546-1548). Nas visitações de Évora, aparece referência à estadia do judeu David, que viria a ser queimado pela Inquisição de Llerena, em Évora (IAN/TT, Inquisição de Évora, liv. 588, fls. 96v-97r). No TAVARES, «The Castilian Jews in Portugal», abordámos já a presença de alguns cristãos novos de origem castelhana que se fixaram em Évora.

${ }^{305} \mathrm{M}^{\mathrm{a}}$ J. Ferro Tavares, «Os Judeus da Beira interior: A comuna de Trancoso e a entrada da Inquisição», Sefarad 68 (2008), 369-411, e 69 (2009), 101-129; IAN/TT, Inquisição de Évora, n $^{\circ} 8066$ (Rui Vaz, 1542-45). 
Jorge Eanes, mercador de panos em Évora, era natural de Segovia. Estava casado com Leonor Fernandes, filha também de judeus que tinham entrado em Portugal quando da expulsão dos judeus de Castela. A sua riqueza estava avaliada em 20000 cruzados de ouro. Eram sogros do Dr. António Barbosa, físico do infante D. Henrique ${ }^{306}$. Maria Dias nascera em Valencia de Alcántara e deve ter-se fixado em Portalegre, onde casara, antes de ir residir para Évora ${ }^{307}$. De pais, judeus de Toledo, era filho o ferreiro Rafael Correia, residente em Évora, à Palmeira ${ }^{308}$. Também desta cidade castelhana vieram Mor Lourenço, a fuseira, e seu marido Heitor Nunes, ferreiro. Fixaram-se em Moura, no Alentejo. Quando entraram em Portugal, em 1492, traziam consigo três filhos, um rapaz, casado com uma castelhana, e duas raparigas. Apenas uma sobrevivera, a que se chamava Alegria. Fora baptizada com o nome de Catarina e casara com um mourisco, oleiro, natural de Moura ${ }^{309}$.

De Talavera de la Reina era natural Catarina Gonçalves, viúva de António Caldeira, tecelão de panos de linho, também ele natural desta cidade castelhana. Como seu segundo marido, Catarina tivera um Navarro. O pai era João de Uzeda e falecera em Évora ${ }^{310}$. Da mesma cidade castelhana proviera Fernando Álvares, peliteiro, casado com Guiomar Rodrigues, nascida em Escalona ${ }^{311}$. De Cáceres era oriundo o serralheiro Manuel Galindo, «José» em judeu. Os progenitores eram naturais de Cáceres, o pai, e de Medellín, a mãe Miracete. Um dos irmãos morreu em Alburquerque. Ele e os pais viveram três anos em Fez e cinco em Alcácer Quibir a mando do rei de Portugal, até que este lhes ordenou que regressassem ao reino ${ }^{312}$. Em Trujillo, nascera Isabel Fernandes, a Lobata, mulher de Henrique Fernandes, o Lobato, enquanto de Oropesa viera o velho alfaiate Fernão Álvares, o

\footnotetext{
${ }^{306}$ IAN/TT, Inquisição de Évora, no 6013 (Leonor Fernandes, 1543).

${ }^{307}$ IAN/TT, Inquisição de Évora, $\mathrm{n}^{\circ} 9101$ (Maria Dias, 1541-1545).

${ }^{308}$ IAN/TT, Inquisição de Évora, $\mathrm{n}^{\circ} 6086$ (Rafael Correia, 1541-1543).

${ }^{309}$ IAN/TT, Inquisição de Évora, no 5171 (Mor Lourenço, 1542-1546).

${ }^{310}$ IAN/TT, Inquisição de Évora, n $^{\circ} 5992$ (Visitação de 1555).

${ }^{311}$ IAN/TT, Inquisição de Évora, $\mathrm{n}^{\circ} 6122$ (Fernão Álvares, 1542-1543).

${ }^{312}$ IAN/TT, Inquisição de Évora, no 6042 (Manuel Galindo, 1542-1543).
} 
Tamanho. Era viúvo de Ourovida. Ambos tinham sido baptizados em Évora. Ele acabaria entregue à justiça secular e relaxado ${ }^{313}$.

Já os Zeimoto, Luís Fernandes, tecelão (ol. José), e a sua mulher Catarina Dias (ol. Raquel), vinham da região de Plasencia. Ele nascera em Valverde (de la Vera) e ela em Alba de Tormes ${ }^{314}$. Outro casal de origem castelhana era Pedro Esteves e Maria Dias. Ele nascera em Coria. Fora vidreiro e carniceiro. No Livro da Visitação, a mulata destes denunciara-os e aos filhos, porque se juntavam na casa de $\mathrm{Si}$ mão Fernandes, co-sogro daquele, e antes na casa de Jorge de Orta. Durante a semana santa comiam pão ázimo que coziam num forno que ficava na travessa que ia para S. João das Freiras ${ }^{315}$. De Garrovillas (Cáceres), vieram o sapateiro Lourenço Salvado (ol. Abraão), e sua mulher Margarida Rodriges. Esta era irmã de Isabel Lobata, mulher do Lobato ${ }^{316}$.

Rui Vaz (ol. Yoced), era natural de Valencia de Alcántara. Pertencia a uma das famílias de judeus castelhanos que entraram pela portagem de Marvão, tendo-se dirigido a Portalegre e depois a Cabeço de Vide onde receberiam o baptismo. A sua segunda mulher nascera em Trujillo e era a mãe dos seus sete filhos, pois a primeira falecera pouco depois do casamento e era de Cabeço de Vide. Já casado iria residir para Arraiolos onde se fixaria como alfaiate, trabalhando para os frades do mosteiro dos Lóios, em Évora, e do mosteiro de Nossa Senhora da Assunção em Arraiolos. Os filhos adultos estavam dispersos pelo reino: Fronteira, Silves, Lagos. Os restantes residiam em Arraiolos. Tinha duas irmãs vivas: uma morava em Évora e a outra tinha regressado a Castela, não sabendo ele bem onde vivia se em Ronda, se em Málaga ou em Sevilla. Um dos sobrinhos tinha ido viver para Itália. Professava simpatias pelas ideias de Lutero, nomeadamente no que se referia à confissão ${ }^{317}$.

${ }^{313}$ IAN/TT, Inquisição de Évora, $\mathrm{n}^{\circ} 9476$ (Isabel Fernandes, a lobata, 1543-1549), $\mathrm{n}^{\circ}$ 6116 (Fernão Álvares, o Tamanho, 1541-1543).

${ }^{314}$ IAN/TT, Inquisição de Évora, no 9416 (Luís Fernandes, o Zeimoto, 1541-1543).

${ }^{315}$ IAN/TT, Inquisição de Évora, $\mathrm{n}^{\circ} 11357$ (Pedro Esteves, 1541-1543); Visitação de Évora, liv. 83, fls. 36v-37r.

${ }^{316}$ IAN/TT, Inquisição de Évora, no 7646 (Lourenço Salvado, 1542-1543).

${ }^{317}$ IAN/TT, Inquisição de Évora, $\mathrm{n}^{\circ} 8066$ (Rui Vaz, ano de 1542-1545). 
Catarina Gomes (ol. Reina), era natural de Segura de la Sierra (Segura de León, Badajoz) e viúva de João de Toledo, relaxado pela Inquisição de Llerena. De Segura foram viver para Sevilla e daqui para Zafra (Badajoz), próximo da fronteira portuguesa de Barrancos, onde se baptizaram. O marido era corretor. Ela veio para Portugal com as filhas e os genros já cristã, tendo-se fixado em Moura com a família. Passado pouco tempo foi residir para Tavira, tendo regressado novamente a Moura. Duas das filhas tinham saído reconciliadas em Llerena. Uma das filhas, Leonor Gomes estava casada com Diogo Fernandes Guzman, sapateiro, natural de Llerena e residia com ela em Moura, na rua de Santa Comba, no interior da vila, depois de ter passado por várias casas em ruas diferentes da vila. Constava que tinham vindo para Portugal fugidos à Inquisição de Llerena. Catarina Gomes vendia beatilhas na sua tenda ${ }^{318}$.

Muitos dos cristãos novos de origem castelhana eram artesãos, como o sapateiro Gabriel Mendes, residente em Arraiolos e natural de Olivença. Era casado com uma castelhana parente de Francisco Mendes Benveniste, morador em Lisboa ${ }^{319}$. Duarte Melo e Brianda Fernandes, tinham sido judeus castelhanos de Plasencia que se tinham fixado em Alter do Chão, vila que não tinha conhecido um passado português judaico. Os filhos dispersaram-se por Arraiolos e por Fronteira, concelhos com antigas judiarias. Nos testemunhos de defesa, João Nunes Carvalhal, fidalgo da casa real, declararia que uma tia paterna, Violante, casara com Fernão de Melo, capitão da ilha de S. Tomé, pelo que a família judaica tomara o apelido cristão de Melo $^{320}$.

No Alvito, onde existiu uma pequena comunidade de judeus fixaram-se alguns dos imigrantes de 1492, como Gabriel Dias e sua mulher Catarina Rodrigues, a Cohena, filha de D. José Cohen. Eram naturais de Toledo. O nome judaico de Catarina era Sol. Recordava bem as orações judaicas como Shema Israel e gostava de cozinhar as argolas de pão ázimo que distribuía por outras cristãs novas, durante a Pessah. Era idosa quando foi presa na Inquisição e recusaria abjurar a sua fé. Também nesta

\footnotetext{
${ }^{318}$ IAN/TT, Inquisição de Évora, $\mathrm{n}^{\circ} 8849$ (Catarina Gomes, 1542-1543).

${ }^{319}$ IAN/TT, Inquisição de Évora, no 3270 (João Lopes, 1543-1546).

${ }^{320}$ IAN/TT, Inquisição de Évora, no 3652 (Fernão de Melo, 1543).
} 
vila alentejana se tinha fixado a velha Isabel Nunes, também ela originária de Castela ${ }^{321}$.

Os pais de Mor Rodrigues, moradora em Arronches, eram como ela naturais de Badajoz. Casara naquela vila portuguesa com um sapateiro cristão novo chamado Lopo Rei. Os seus irmãos viviam como ela em Arronches, enquanto os tios maternos se tinham fixado em Campo Maior ${ }^{322}$.

João Lopes ou João Biscainho era natural de Castela e tinha cerca de sessenta anos quando fora preso pela Inquisição. Fora correeiro do cardeal D. Afonso. Casara com uma cristã velha, Beatriz Fernandes, e residia na Correaria, em Lisboa. Possuia uns moinhos na ribeira de Loures, nos arredores da cidade. Confessava ter em sua casa um livro em língua castelhana que se intitulava Genesis alfonsi, semelhante a outros que tinham sido queimados com Bíblias e livros de Erasmo por ordem da Inquisição. Os pais quando vieram de Castela ficaram a residir em Évora ${ }^{323}$.

Já Branca de Sousa, natural de Tavira e residente em Faro, era filha de uma judia de Toledo, Leonor Gerardo, e de mestre Duarte, físico. Tal como sua mãe, casara com um físico e cirurgião de Faro, mestre Francisco, que também se dedicava aos negócios. Era armador. Era cunhada de Rui Martins Pedrosa, mercador e armador que exportava sardinhas em barricas de madeira para Espanha e sul de Itália, nomeadamente para Nápoles $^{324}$.

Outros derivaram para o norte de Portugal. Foi o caso de Afonso Garcia, sapateiro. Era natural de Fermoselle (Zamora) e ficou a viver em Mogadouro onde casou com uma cristã nova natural deste concelho. Os pais eram judeus de Fermoselle, onde ainda viviam alguns dos seus irmãos, como o sapateiro Pedro Garcia, a irmã Catarina Garcia casada com Francisco Manriques. A irmã mais nova residia em Valladolid com uma tia ${ }^{325}$.

Fernão Vasques entrou em Portugal com quatro anos de idade juntamente com a sua família. Era natural de Dueñas (Palencia). Encontrava-se em Lisboa quando D. Manuel, a 19 de Março de 1497, decretou que

\footnotetext{
${ }^{321}$ IAN/TT, Inquisição de Évora, ${ }^{\circ} 7957$ (Catarina Rodrigues, 1543-1548).

${ }^{322}$ IAN/TT, Inquisição de Évora, ${ }^{\circ} 11359$ (Mor Rodrigues, 1546-1548).

${ }^{323}$ IAN/TT, Inquisição de Lisboa, $\mathrm{n}^{\circ} 13217$ (João Lopes, 1539).

${ }^{324}$ IAN/TT, Inquisição de Évora, $\mathrm{n}^{\circ} 458$ (Branca de Sousa, 1545-1549).

${ }^{325}$ IAN/TT, Inquisição de Évora, no 4637 (Afonso Garcia, 1544-1548).
} 
fossem retiradas as crianças judias aos seus pais. Foi baptizado em S. Vicente de Fora. Já adulto foi viver em Santarém, onde aprendeu o ofício de tecedor de alambéis do rei e casou com Catarina Ribeira.

Integraria o grupo de cristãos novos deste concelho e arredores que seria preso na Inquisição de Lisboa pelas suas crenças messiânicas. Tinha 63 anos quando tal aconteceu e confessaria que conversava sobre a vinda do Messias com Alonso Sanches, um velho alfaiate de 80 anos, também como ele de origem castelhana. Confessaria guardar a Páscoa judaica com a mulher, descansando os dois primeiros dias da semana e comendo aipo com alfaces em lembrança da saída dos judeus do Egipto, o pão ázimo que a mulher cozinhava em casa acompanhado com nozes e figos, jejuar o yom quipur agregando o filho mais velho que residia com os pais pelo que o designavam por behoc, guardar o Purim da rainha Ester, jejuando um só dia em vez dos três, jejuar o Thisabeat. Recitava em hebraico a Shema Israel.

Acrescentava que o tempo das festas e dos jejuns lhe eram transmitidos secretamente por um cristão novo chamado Monroy ou Moyroyo ou por Gabriel Mendes. Acreditava que o Messias prometido ainda não tinha vindo e que havia de vir pela era de Noventa, conquistaria Roma,

e que o seu cavalo havia de comer sobre o altar, corroborando isto e provando com certas trovas feitas à maneira de profecia que os rabinos fizeram.

Mas antes de o Messias vir, os Turcos destruiriam a cristandade. E recitava umas trovas:

serão em um ser as três opiniões sem haver em eles mais cisma, sem haver óleo nem crisma serão renovados os corações, ninhos de cunha serão humilhados, haverá crença fazendo ao Alto uma tal reverência por onde mereçamos inteiros perdões ${ }^{326}$.

Luís Fernandes era natural de Córdoba, da geração dos «confessos», segundo declarava na Inquisição de Lisboa, para onde fora conduzido preso por defender com outros cristãos novos crenças messiânicas, a partir dos movimentos luteranos na Alemanha, da cisão inglesa e de certas trovas que corriam em Portugal e em Castela, sobretudo em Se-

${ }^{326}$ IAN/TT, Inquisição de Lisboa, no 2466 (Fernão Vasques, 1554). 
villa, nomeadamente as de Santo Isidoro. O grupo a que pertencia era, tal como ele, definido maioritariamente por ourives do ouro e da prata que residiam em Lisboa e que, como ele, se encontravam presos. Um seu colega, Afonso Rodrigues costumava ler os Salmos por um Saltério em português. Outro, o Montemor, Sebastião Fernandes era o que recitava de cor as trovas de Santo Isidoro em castelhano e declarava que os acontecimentos na Europa eram sinais da vinda próxima do Messias e de que a Lei havia de ser uma, a dos judeus. Acreditavam que o Messias viria antes de a década de 90 ser descoberta ${ }^{327}$.

As relações com o reino de origem dos antepassados eram mantidas pelos imigrantes baptizados. $\mathrm{O}$ comércio com Castela fora uma realidade enquanto judeus e permanecia após o baptismo, quando os descendentes já tinham nascido em Portugal. Fernão Ximenes e Joana Nunes eram castelhanos e fixaram-se na Covilhã onde nasceram e foram baptizados os filhos Francisco Ximenes, mercador e rendeiro das rendas dos dízimos do cardeal infante D. Henrique, residente em Évora, Isabel Ximenes, viúva de Fernão Álvares, moradora na Guarda, Beatriz Ximenes, casada com António Rodrigues Galvão, mercador e aqui moradores, Francisca Ximenes, viúva de Jorge de Matos, ourives e mercador da Covilhã, o dr. Duarte Ximenes, físico do rei D. João III e antes do infante cardeal D. Afonso, filho de D. Manuel, e Gaspar Ximenes, mercador em Évora. Duarte Ximenes casara com Isabel Rodrigues, filha de mestre Rodrigo, físico, cristão novo e Gaspar tomara por mulher, Isabel Pires, irmã da primeira esposa de Francisco Ximenes. Francisco Ximenes costumava frequentar a feira de Medina del Campo e tinha negócios em Bilbao e na ilha de S. Tomé ${ }^{328}$.

Gabriel da Tabuada Cavaleiro era filho de Lopo da Tabuada, natural da Galiza. A sua mãe era uma judia, nascida no Porto. Casara em Beja com Beatriz Fernandes, antes de vir viver para Lisboa. Daqui embarcaria para a Índia à procura de fortuna, mas não teria sucesso, regressando, por isso, empobrecido. Era mestre de crianças. Seria apanhado pela Inquisição sob a acusação de ser seguidor do sapateiro de Trancoso, o Bandarra, e das suas trovas de cariz messiânico ou interpretadas pelos cristãos novos com tal sentido. Gabriel residia nas casas que foram de mestre Gabriel,

${ }^{327}$ IAN/TT, Inquisição de Lisboa, $\mathrm{n}^{\circ} 3489$ (Luís Fernandes, 1562).

${ }^{328}$ IAN/TT, Inquisição de Évora, ${ }^{\circ} 11761$ (Francisco Ximenes, 1542). 
um dos mais activos cristãos novos de Lisboa defensor dos ideais messiânicos e local de reunião dos cristãos novos de diversa proveniência. Aqui falavam sobre Henrique VIII e sobre Lutero. Comentavam o Antigo e o Novo Testamento que Gabriel da Tabuada costumava ler numa bíblia que possuía escrita em italiano e entregara a João Fernandes, livreiro ${ }^{329}$.

Joana Lopes residia entre Évora e Lisboa, pois o marido Diogo de Madrid era cortesão. Era sogra de Francisco de Madrid casado com Branca Lopes, sua filha, que também estava presa por suspeitas de judaísmo. Um seu sobrinho estava casado com uma irmã de Simão de Oliveira, recebedor da chancelaria real. Era parente de mestre Jorge de Valadares, físico e cirurgião. Também ela depois de uma primeira prisão e ter abjurado, não receava criticar a morte pelo fogo dos cristãos novos, como fora o caso de Manuel da Costa, acusado de ter afixado certos panfletos contra a fé católica na porta da Sé de Lisboa, nem tão pouco de comentar a actuação de Salomão Molcho ou de Lutero, em Roma, entendendo que era profeta santo dos judeus ou o Messias prometido ${ }^{330}$.

Rui Dias, confeiteiro do rei, tivera parentes queimados em Castela e em Roma, o que nos permite pressupor que os seus ascendentes teriam vindo do outro lado da fronteira. Aliás fora baptizado em Olivença, onde lhe puseram o nome de Rafael, o qual fora mudado em Rodrigo quando fora crismado também nesta vila. Foi acusado e confessaria estar a aprender hebraico e as cerimónias judaicas com o castelhano Montenegro que seria queimado por judeu e feiticeiro. Montenegro ensinava-lhe hebraico por uma Bíblia poliglota que continha o hebraico, o latim, o grego e o «caldeu» (aramaico). A circulação de Bíblias era uma realidade de tal modo que Rui Dias seria acusado de procurar quem possuísse uma Bíblia em hebraico ou em português. O confeiteiro pensara abandonar o reino e ir viver para a Flandres, tal como outro velho castelhano de nome Simão Lopes. Deste desejo foram desaconselhados pelo Montenegro que afirmava que o Messias estaria para breve, na década de quarenta. Mas não era só este converso a atrair os cristãos novos para o judaísmo. Abraão Benzamerro, judeu de sinal, também ensinara Rui Dias e outros a guardar as cerimónias judaicas e quando fugido à Inquisição recolhera-se em

\footnotetext{
${ }^{329}$ IAN/TT, Inquisição de Lisboa, $\mathrm{n}^{\circ} 13212$ (Gabriel Tabuada Cavaleiro, 1541).

${ }^{330}$ IAN/TT, Inquisição de Lisboa, $\mathrm{n}^{\circ} 3223$ (Joana Lopes, 1539).
} 
casa do livreiro e luveiro Jorge Mendes que também convivera com rabi Abraão Zacuto, astrólogo, e com Isaac Benzamerro, judeu de sinal. Jorge Mendes ouvira Zacuto predizer para breve tempos messiânicos ${ }^{331}$.

Em Lisboa, fixaram-se os Benveniste que, cedo, como mercadoresbanqueiros tiveram o seu lugar na corte mercantil de D. Manuel. As suas relações com Antuérpia como feitores do rei na compra de prata para a casa da moeda de Lisboa estão aqui documentadas. Geralmente, conhecemos Gracia Nasi, mulher de Francisco Mendes-Benveniste, e cunhada de João Micas, duque de Naxos, e esquecemos os Henriques-Nunes, seus parentes, e mercadores como eles que os seguiram no seu périplo para Itália. Nuno Henriques ou Sénior Benveniste e Henrique Nunes, seu irmão, eram filhos de pais judeus castelhanos. Eram mercadores com negócios na corte e bem relacionados com D. Miguel da Silva, bispo de Viseu e conhecido como o «cardeal de Portugal», razão da sua queda em desgraça junto de D. João III. Com Jorge de Leão, faziam parte da «cabeça» dos cristãos novos de Lisboa que procuravam com o apoio do ex-bispo de Viseu impedir a entrada da Inquisição em Portugal ou minimizar os seus efeitos para os cristãos novos e suas fazendas.

Com a entrada da Inquisição no reino sentiram as suas vidas e as das suas famílias ameaçadas e decidiram partir para a Flandres e daqui para Itália. Fizeram-no entre 1542-45. Antes de embarcarem ter-se-iam escondido em casa de Diogo e Luís de Crasto. Um parente dos Abravanel afirmaria com precisão 1544 como o ano de saída da família para a Flandres, numa nau. «Juntaram as suas casas» e partiram, diria uma outra das testemunhas à Inquisição de Lisboa. A família, entretanto, cruzara-se com os Negro, pois uma irmã destes, talvez Violante Henriques, casara-se com Gabriel ou Moisés Negro, talvez o mestre Gabriel, o rabi mencionado em muitos dos primeiros processos de cristãos novos de Lisboa.

Nuno Henriques acabaria por falecer em Veneza onde se instalara, deixando uma grande riqueza monetária. Só à sua viúva Violante (ol. Velida), que viria a partir para a Turquia onde se tornaria judia, deixava metade do património, a Jerónimo, Sénior no interior da família, o filho mais

${ }^{331}$ IAN/TT, Inquisição de Lisboa, $\mathrm{n}^{\circ}$ 3853, 3856 (Rui Dias, 1539) e 3858 (1541); $\mathrm{n}^{\circ} 5322$ (Jorge Mendes, 1539). Os Benzamerro eram judeus de Safim que vinham frequentemente à corte de Lisboa onde negociavam e davam informações ao rei D. João III sobre os assuntos do norte de África. 
velho legava 10000 ducados, e aos outros filhos e filhas doava a cada um 6000 ducados. Na corte de Leonor de Toledo, duquesa de Florença, mulher de Cosme de Médicis, encontravam-se cristãos novos portugueses e cristãos velhos portugueses e espanhóis. No cruzamento dos caminhos dos negócios e sociais era fácil a suspeita destes sobre aqueles, tanto mais que o comportamento de muitos deles era dúplice: cristãos e judeus. Seu filho, Henrique Nunes, cujos processos nas inquisições de Veneza e de Lisboa conhecemos, assumira-se judeu em Ferrara, onde afirmava residir e ter nascido, como Abraão Benveniste. Seria um português, cristão novo como ele, João António Vizinho quem testemunharia o seu nascimento em Lisboa e o seu baptismo o que viria a ser confirmado pelo pároco da igreja da Madalena, embora uma testemunha cristã velha, antiga criada da família dissesse que ele teria sido baptizado na igreja de Santo António do Tojal, quando residiam em Pêro Viegas, nos arredores de Lisboa, por altura do tremor de terra de 1532 e da peste. Confirmavam o seu nascimento e baptismo alguns espanhóis e portugueses, alguns deles cristãos novos, como Afonso de Torres, Diogo de Castro del Rio, Diogo Fernandes Abravanel, Manuel Caldeira e Álvaro de Cáceres, músico, cantor e comediante na corte em Madrid, entre outros. Este último viria a ser preso pela Inquisição de Évora, em 1571, e entregue à justiça secular por culpas de judaísmo.

A família tinha interesses comerciais em Veneza, Ferrara, Ancona, França, Antuérpia e Portugal. Ele era definido por mercador honrado e bastante rico. Deslocara-se várias vezes a Espanha e a Portugal em negócios, sobretudo, para receber dinheiros dos bens que aqui tinha. Em Lisboa, tanto usava o nome Henrique Nunes como Gomes Camelo. Numa das suas deslocações ao reino para receber dinheiro seria preso. Abraão Benveniste ou Henrique Nunes acabaria reconciliado pela Inquisição de Lisboa depois de ter sido preso em Veneza. A mãe e as irmãs partiriam para o Império otomano onde viviam como judias em Constantinopla e em Salónica, enquanto uma outra ficava em Ferrara casada com D. Leão Abravanel, nascido em Nápoles, tal como um dos cunhados, viúvo de uma sua irmã já falecida, o licenciado Manuel Reinel que como judeu se designava Abraão Bendara.

No seu depoimento no Tribunal de Lisboa, declararia ter conhecido em Bordéus um Lopo de Mena que vivera muito tempo na Galiza. Em 
Medina del Campo, declarara-se judeu aos Tristões, cujo pai tinha apelido Vilhalpando, os quais pretendiam juntar-se aos progenitores que se tinham acolhido a Salónica ${ }^{332}$.
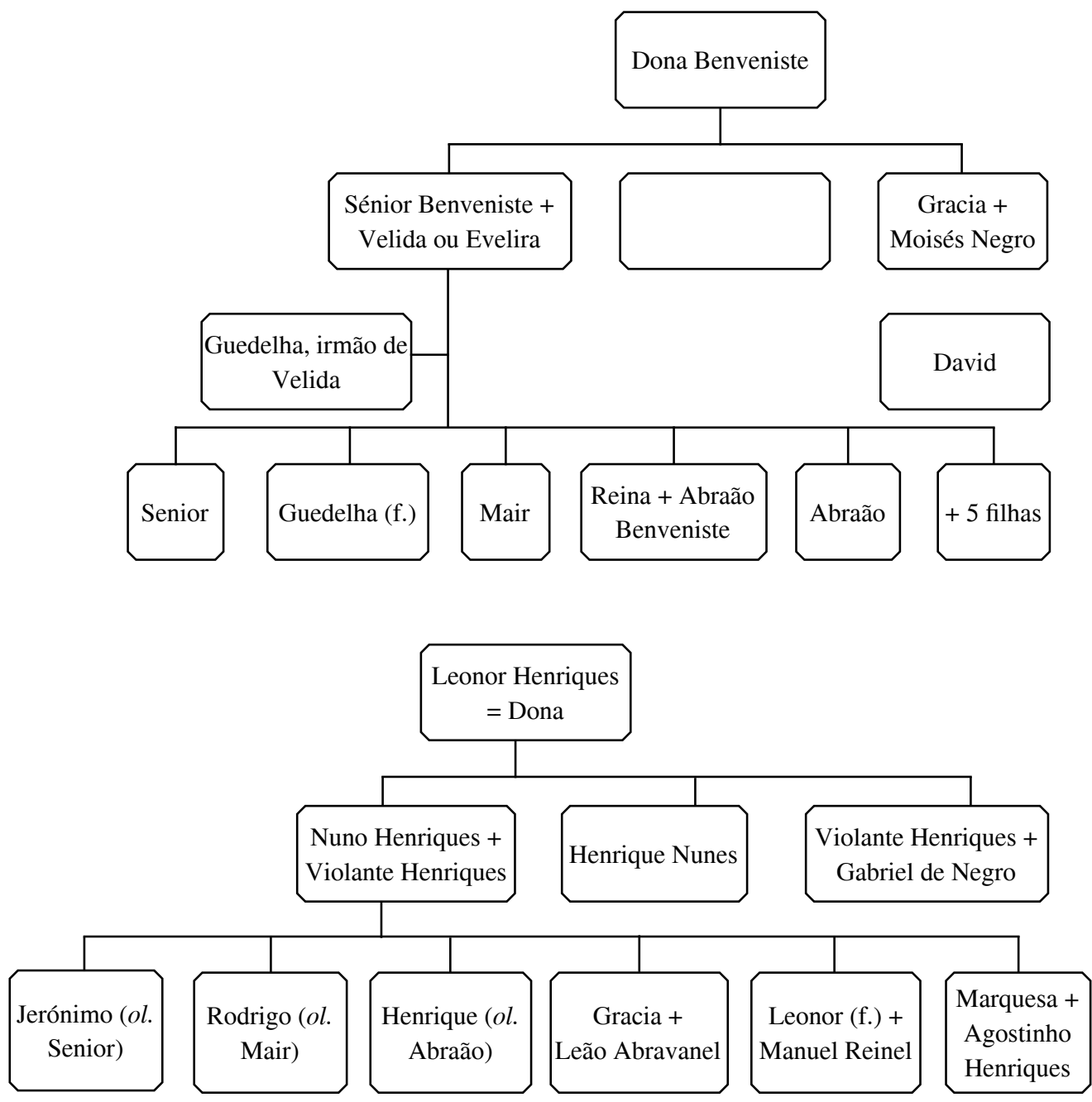

${ }^{332}$ P. C. Ioly Zorattini, Processi del S. Uffizio di Venezia contro Ebrei e Giudaizzanti (1570-1572) (Firenze: Leo S. Olschki Editore, 1984), 8 (nota 2) e 7-34. Ioly Zorattini publicou neste volume os processos da Inquisição de Veneza e de Lisboa, assim como outros documentos avulsos respeitantes a esta família. 
Verificamos pelas três gerações destes Benveniste que, em Portugal, se cruzaram com os Negro (Ibn Yahia) e em Ferrara com os Abravanel e os Reinel. Gabriel de Negro (ol. Yahia) estivera para casar com a sobrinha que, enquanto ele andara pelo Levante, pelo que não chegara a receber o baptismo, acabara por casar com Nuno Henriques. Isto significa que Violante era uma Ibn Yahia. Do casamento de Violante Henriques e Gabriel de Negro nascera na Flandres um filho, David, que seria cunhado de Abraão Benveniste, pelo seu casamento com uma sua irmã.

No seu depoimento, referiria uns cristãos novos de Portalegre, mercadores, que se assumiriam como judeus em Itália adoptando o apelido Navarro e que no reino usavam o apelido Pinheiro. Outro Navarro saíra do Algarve. Também para Ferrara tinham partido os Fontes de Évora que aqui tomaram o apelido Allalvo. Para Veneza, depois da passagem pela Flandres, como muitos outros, fora João Cohen de Lara. No final da sua vida e já depois de reconciliado e catequizado, o agora Henrique Nunes solicitava aos inquisidores permissão para ir viver para Castela onde tinham familiares e tinha dívidas para receber de onde podia obter algum dinheiro para sobreviver ${ }^{333}$.

No processo de Filipa Jorge, confeiteira, em Veneza, mulher de Duarte de Aguiar, encontramos a menção a um cristão novo que ao assumir-se judeu adoptou o apelido Navarro. Filipa Jorge teria ido para Antuérpia e Ferrara no séquito de Gracia Nasi ${ }^{334}$.

Francisco Tomás nascera em Viana do Castelo. Filho do licenciado António Fernandes, médico, e de Graça Tomás, natural de Santiago de Compostela, cidade onde continuavam a viver uma tia freira e duas primas. Ele seria o exemplo daquilo que a literatura e a história designou por «judeu errante». Nascido em Portugal de, pelo menos, mãe galega, partiria ainda criança para Ferrara, onde a família se assumiria como judia. Aqui, ele e os irmãos foram circuncidados, e frequentaram a escola na judiaria de Ferrara onde aprenderam a ler hebraico e as orações da Lei na sinagoga. De Ferrara, partiria para França onde trabalhou, em Lyon e Bordéus, com um

${ }^{333}$ Ioly Zorattini, Processi del S. Uffizio di Venezia contro Ebrei e Giudaizzanti (1570-1572), 219-286.

${ }^{334}$ Ioly Zorattini, Processi del S. Uffizio di Venezia contro Ebrei e Giudaizzanti (1571-1580), 76-79. 
mercador francês Francisco Clémanceau, servindo de intérprete nos negócios que este tinha com mercadores portugueses. Em negócios, esteve na Gasconha e daqui foi a Tunes e à Corunha levando e trazendo mercadorias. Em representação de dois mercadores portugueses, Fernão Nunes da Costa, tesoureiro da casa de Ceuta, e André Soares levaria um navio carregado de trigo até à Madeira onde o vendeu. No regresso, passou por Lisboa.

Neste seu itinerário, cruzou-se com inúmeras famílias de portugueses que se lhe declaravam ser judeus. Comunicava com o cristão novo Henrique Nunes (Benveniste) em Ferrara, mas também em Bordéus onde este tinha uma sinagoga e onde os portugueses de origem judaica se reuniam para orar. Nesta cidade francesa vivia um tio de Francisco Tomás, Adão Francisco, parente paterno, que frequentava a casa de António Rodrigues Navarro, natural de Lisboa, que possuía livros em castelhano. Em Lyon reuniam-se os cristãos novos em casa do judeu português chamado Rodrigo de Aguiar.

Enquanto negociava, a família, incluindo o tio Adão Francisco, tinham partido para Salónica onde viviam. Como «francês» passara a residir na Madeira, onde casara com uma cristã velha e passara a comportar-se como cristão. Enredado nos processos e denúncias dos cristãos novos madeirenses acabaria por confessar ter seguido a Lei de Moisés ${ }^{335}$.

Mas, nem todos se confinaram ao espaço do território do continente e foram para outras paragens ultramarinas, como Fernão Álvares, o castelhano, que foi residir no Funchal, na rua dos Medinas. Era viúvo e dizia-se natural de Olivença, devendo este concelho ter sido o local onde os pais. Diogo Álvares, mercador, e Catarina Dias, se fixaram com ele, e prévio à sua emigração para a Madeira, com quinze anos de idade. Fora baptizado e crismado pelo bispo D. Diogo Ortiz, na igreja da Madalena em Olivença.

Era mercador e rendeiro dos moinhos, talvez, associados à produção do açúcar. Nos seus negócios deslocava-se a Lisboa e a Sevilla. No Funchal, residia com a sua família próxima, filhas, sobrinhos, sendo denunciado e preso na Inquisição de Lisboa por culpas de judaísmo. Pertencia ao círculo de parentes de Ana Dias em cuja casa havia a confraria de Nossa Senhora com um retábulo que Afonso Fidalgo levara de Lisboa e era pretexto para aos sábados os familiares e amigos desta se reunirem e cumprirem o des-

${ }^{335}$ IAN/TT, Inquisição de Lisboa, no 8937 (Francisco Tomás, 1584). 
canso sabático. Jejuava os thanis de segunda e quinta, assim como o yom quipur, o jejum do «tempo dos marmelos». Amortalhara a mulher, Beatriz Gomes, irmã de Ana Dias, ao modo judaico, ou seja, em lençol novo nunca usado. Costumava rezar os Salmos sem a Glória e recordava rezando uma oração judaica «Nosso Senhor, Adonai, salvai-me». Guardava as Páscoas dos judeus e recusava comer os alimentos proibidos pela Lei de Moisés. Veio preso para o cárcere da Inquisição de Lisboa, onde confessaria a sua crença de maneira não satisfatória pelo que seria posto a tormento de potro. Condenado a hábito penitencial perpétuo e a ser instruído na doutrina cristã, faleceria a cumprir a penitência que lhe fora ministrada ${ }^{336}$.

O genro Diogo Mendes regressara a Castela, para Mougel [?], terra de Sevilla, onde vivia com a mulher, Catarina Dias, segundo o testemunho de Maria Ribeira ao inquisidor Jerónimo Teixeira Cabral, durante a visitação que fez à ilha. Segundo o testemunho da mesma, o Castelhano, tinha uma irmã a residir no Funchal onde era fanqueira, a qual vivia próximo dos açougues numas casas grandes de dois sobrados ${ }^{337}$. A relação com as raízes mais ou menos longínquas tinha repercussões no destino económico dos descendentes. Branca Mendes, filha do Castelhano, informava na sua genealogia que o tio materno, Diogo Mendes, se encontrava no Peru, e o mesmo sucedia com os seus irmãos mais velhos que residiam neste território da América espanhola, enquanto um outro, Garcia Álvares, estava nas Índias espanholas. O irmão frade franciscano encontrava-se nas Canarias e a irmã Catarina Dias e o marido tinham ido viver para $\mathrm{Cádiz}^{338}$.

António Pereira, mercador, rendeiro e produtor de açúcar nasceu em Braga de pais castelhanos, Inigo Lopes, natural de Villalón, e de Mécia Lopes. O pai comerciava em açúcar que levava para Castela e daqui trazia panos e fora viver para a Madeira a pedido de D. João III. Os filhos repartiam-se entre o Funchal, Lisboa, S. Miguel e Angra, nos Açores, a Flandres e Antuérpia ${ }^{339}$.

${ }^{336}$ IAN/TT, Inquisição de Lisboa, no 12090 (Fernão Álvares, o castelhano, 1591).

${ }^{337}$ IAN/TT, Inquisição de Lisboa, $\mathrm{n}^{\circ} 6435$ (Branca Mendes, 1593).

${ }^{338}$ IAN/TT, Inquisição de Lisboa, ${ }^{\circ} 6435$ (Branca Mendes, 1593); Inquisição de Lisboa, liv. nº 790 (Relatório dos culpados na visitação da ilha da Madeira), fls. 9r, 15r.

${ }^{339}$ IAN/TT, Inquisição de Lisboa, no 9552 (António Pereira, 1586). 
Outros cristãos novos que aqui residiam mantinham apelidos judaicos como era o caso de Francisco Caro casado com Elvira Gonçalves, Francisco de Medina ${ }^{340}$.

As Canarias eram também local intermédio para se atingir a Madeira ou local de refúgio quando os negócios ou a instabilidade religiosa o exigiam. Isabel Gomes, natural de Elvas ou de Olivença, saiu com o marido de Lisboa para Tenerife onde residiram alguns anos antes de atingir a Madeira. $\mathrm{O}$ marido fora para Lanzarote de onde lhe enviava mercadoria para o Funchal que ela depois vendia na cidade. Um filho casara com uma sobrinha de Fernão Álvares, o castelhano, um outro casara em Tenerife com Beatriz Neta, natural desta cidade, a filha continuava a residir no Funchal $^{341}$.

A ascendência castelhana de outros permanecia no apelido judaico tornado alcunha, como acontecia com os Vitória, como António Rodrigues Vitória e o seu primo e cunhado Francisco Rodrigues Vitória. Foram acusados de negociarem com os holandeses no Brasil, pelo que aquele teria os bens confiscados para a coroa por Filipe II, em 1605. A irmã deste último, Leonor Rodrigues Vitória, estava casada o mercador Francisco Fernandes de Tavira, também acusado de comerciar com os inimigos. Outra cristã nova de ascendência castelhana era Beatriz de Medina, natural de Lisboa, freguesia de S. Julião, e mulher de Gaspar Fernandes. Por sua vez, Salvador Álvares casaria com Beatriz Guterres, natural das Canarias. De Toledo, freguesia de Santa Leocádia, vieram Bartolomeu da Veiga e Ana Loaysa, sua mulher ${ }^{342}$. Uma neta do boticário João Mendes veio a casar com Diogo Lopes de Andrada, natural de Sevilla, seu primo. Este matrimónio teve vários filhos, uns entraram na vida religiosa, como as filhas que se fizeram freiras em Sta. Clara ou um dos filhos que foi cónego na Sé do Funchal. Os outros dois filhos contraíram matrimónio, mas um foi para as Ilhas americanas e o outro foi viver no Maranhão ${ }^{343}$.

${ }^{340}$ IAN/TT, Inquisição de Lisboa, $\mathrm{n}^{\circ} 6991$ (Nicolau Nunes, 1594).

${ }^{341}$ IAN/TT, Inquisição de Lisboa, ${ }^{\circ} 4979$ (Isabel Gomes, 1586).

${ }^{342} \mathrm{~F}$. Barros (transcr.), Rol dos judeus e seus descendentes (Arquivo Histórico da Madeira. Série Transcrições Documentais, 1) [= Boletim do Arquivo Regional da Madeira] (2003), 234-235, 239, 241, 316, 328, 329.

${ }^{343}$ BARros, Rol dos judeus e seus descendentes, 282. 
Mas, neste início do século XVII, a mobilidade permanecia entre os cristãos novos num Portugal integrado na Monarquía Hispánica, como Pedro Soares, alfaiate, natural de Valencia de Alcántara, Pedro Lopes, mercador, e Isabel Dias de Libraleão, oriundos de Sanlúcar de Barrameda via Sevilla, ou Catarina Ordonhes, que nascera em León. Pedro Lopes Libraleão teria um dos filhos casado com uma cristã nova que recordava um passado de sociedades com a família flamenga dos Leme, e uma neta, seria a mulher de outro cristão novo com ascendência italiana, neste caso, os Dória. O boticário Faustino Dias, natural da Calheta (Madeira), foi casar com a castelhana Ana de Aguilar. Todos foram viver para a Madeira e lá constituíram família, dedicando-se a profissões várias e aos arrendamentos ${ }^{34}$. Muitos deles casavam em casa à maneira judaica, não o fazendo à porta da igreja com os banhos e a bênção da Igreja. Tal aconteceu com o Dr. Diogo de Crasto que vivia com a mulher Margarida Ferreira, havia muitos anos. Convidados a casar pela Igreja, acabaram fugindo para as Canarias ${ }^{345}$. As ligações familiares, muitas vezes ancestrais, não se perdiam e elas perduravam no antigo apelido judaico que permanecia no agora cristão novo como alcunha, antes de regressar a apelido, como acontecera com o mercador Francisco Caro ${ }^{346}$.

África era também um espaço de negócio para os cristãos novos de origem castelhana que, à semelhança dos de origem portuguesa criavam as suas redes familiares de negócio. Pedro Martins era meio-cristão novo por parte da mãe. Residia em Lisboa mas era natural de Sevilla. Era mercador, negociando com Azamor, as Canarias e as Antilhas. Um dos filhos, Diogo Martins, encontrava-se em Sevilla e o outro, Henrique Martins de Castanheda, vivia na Berbéria. Um seu parceiro era outro, físico, tinha um filho a negociar em África para onde ele enviava armas que lá eram vendidas ${ }^{347}$.

${ }^{344}$ Barros, Rol dos judeus e seus descendentes, 245, 248, 294, 303-304, 318, respectivamente.

${ }^{345}$ BARros, Rol dos judeus e seus descendentes, 370.

${ }^{346}$ Barros, Rol dos judeus e seus descendentes, 328.

${ }^{347}$ IAN/TT, Inquisição de Lisboa, $\mathrm{n}^{\circ} 6438$ (Pedro Martins, 1551). 


\section{CONCLUSÃo}

Em jeito de conclusão, podemos dizer que Espanha, tal como Portugal, continuava a ser um local de chegada e de partida dos cristãos novos como fora antes dos judeus. A fronteira não os separava, fazendo-se a mobilidade, consoante os interesses em jogo, pelos portos fronteiriços legais mas também pelos clandestinos. A comunicação entre os tribunais da Inquisição era uma realidade que trazia os cristãos novos suspensos e sempre preparados para a partida no maior secretismo possível para que a fuga tivesse sucesso, se ela fosse feita por terra. Violante Rodrigues, cristã nova de Vila Flor, viera presa para Évora. O filho apressara-se a avisar Diogo Vasques (ol. Faram), e outras pessoas da vila que fugiram para Castela. Benito de Leão, filho de Dinis Álvares, relaxado em Lisboa por volta de 1539, tinha um irmão preso na Inquisição de Valladolid ${ }^{348}$.

Catarina Rodrigues, natural e residente em Alburquerque, tinha vários familiares presos na Inquisição de Llerena: uma tia, uma prima e os três irmãos. Ela própria tivera um mandato deste tribunal que fora lido na igreja de Alburquerque. Perante a prisão dos familiares Catarina Rodrigues teve receio e fugiu para Portugal, para Campo Maior, onde acabou por ser presa pela Inquisição de Évora, em cumprimento do mandato que esta recebera de Llerena ${ }^{349}$.

De Ciudad Rodrigo, onde vivia Fernão Rodrigues Caldeira, chegaram as denúncias contra Henrique Nunes que, em La Rochelle, usava outro nome e recusava comer porco e ir à missa ${ }^{350}$. Para Valladolid, fugiu o rendeiro Francisco Rodrigues, quando desconfiou que a Inquisição de Lisboa o pretendia prender. Por outro lado, para Lisboa vieram cristãos novos que tinham sido queimados em estátua em Granada, como João Baptista e Lourenço Peres, ourives, António Peres, mercador na Rua Nova e a mulher de Martim Fernandes. Outros iam denunciar conhecidos à Inquisição de Lisboa como o castelhano Alonso Martins que denunciou Diogo Dias, fugitivo ao Tribunal de Córdoba ${ }^{351}$.

${ }^{348}$ IAN/TT, Inquisição de Évora, liv. 588, fls. 185r e 191r-192r.

${ }^{349}$ IAN/TT, Inquisição de Évora, ${ }^{\circ} 7959$ (Catarina Rodrigues, 1567-1568).

${ }^{350}$ A. BAIÃo, «A Inquisição em Portugal e no Brazil», Archivo Histórico Portuguez. VII (1909), 152.

${ }^{351}$ A. BAIÃo, «A Inquisição em Portugal e no Brazil», Archivo Histórico Portuguez. VIII (1910), 53; VI (1908), 172 e 185. 
Isabel Rodrigues tinha sido reconciliada em Llerena por volta da década de Trinta do século xvi. O pai levara-a para Badajoz e daqui passaram a Portugal, tendo-se fixado em Campo Maior. Estava casada com o ferreiro João Alonso com quem vivia em Santarém. Ele também saíra penitenciado em Llerena, acabando relaxado em Lisboa, por relapso. Isabel Rodrigues fora toda a sua vida taberneira, vendendo também azeite na sua loja. Confessaram-se judeus, jejuando, celebrando as festas judaicas, guardando o sábado, comendo bolos ázimos «altos de três dedos» pela Páscoa $^{352}$.

Entre as denúncias feitas aos visitadores, não ficou esquecida a de que os cristãos novos de Arronches eram castelhanos e eram maus cristãos, tendo sido queimados em estátua em Llerena, encontrando-se os seus sambenitos expostos em Badajoz. Outra informação dizia respeito a Fernão de Molina, residente em Moura, que viera para Portugal fugido à Inquisição espanhola, tendo a sogra sido queimada em Llerena ${ }^{353}$.

Em suma, mesmo após o baptismo, os descendentes dos judeus continuavam a fazer jus ao seu passado sefardita, à pertença a uma comunidade, uma tradição cultural e religiosa, um território que se designava Sefarad e cuja memória permaneceu até hoje, nos apelidos judaicos de origem toponímica castelhana. Assim, continuamos a encontrar os Cáceres, os Catalão, os Córdova, os Vitória, os Medina, de Ledesma, de Zamora, de Valença, de Leão, para já não falarmos dos que ainda hoje perduram como os Navarro, os Abravanel, os Esquerra, por exemplo, já para não falarmos dos apelidos judaicos de origem bíblica.

Recibido: 05/12/2011

Aceptado: 24/05/2014

${ }^{352}$ IAN/TT, Inquisição de Lisboa, $\mathrm{n}^{\circ} 873$ (Isabel Rodrigues, 1555).

${ }^{353}$ IAN/TT, Inquisição de Évora, liv. 588, fls. 243r e 254v. 